\title{
A MODEL OF RURAL DELINQUENCY: COLLECTIVE EFFICACY IN RURAL SCHOOLS
}

\author{
Jennifer Hayman Lackey
}

\author{
A Dissertation \\ Submitted to the Graduate College of Bowling Green \\ State University in partial fulfillment of \\ the requirements for the degree of
}

\section{DOCTOR OF PHILOSOPHY}

December 2016

Committee:

Carolyn J. Tompsett, Advisor

Paul A. Johnson

Graduate Faculty Representative

Eric F. Dubow

Anne K. Gordon 


\begin{abstract}
Carolyn J. Tompsett, Advisor

Social contexts have long been identified as having an impact on adolescent behaviors, including the neighborhood context. However, most literature examining neighborhood influences on juvenile behavior have focused on urban and semi-urban populations. When these urban-centric models are applied to rural populations, results are generally mixed, and oftentimes contradictory to patterns established in urban populations. The current study tested an alternative model for predicting juvenile problems behaviors in rural areas but examining the validity of previous conceptualized "neighborhood collective efficacy" in rural schools. Constructs similar to Sampson et al.'s (1997) neighborhood collective efficacy were found in this sample, and this construct was significantly negatively correlated to juvenile self-reported problems behaviors. As hypothesized, school collective efficacy was more strongly related to self-reported problem behaviors than neighborhood collective efficacy for this sample. Directions for future research and implications for policies are discussed.
\end{abstract}




\section{ACKNOWLEDGEMENTS}

The following list of those individuals who helped make this dissertation possible is extensive and still not all inclusive. I would like to thank my advisor, Carolyn Tompsett for her patience and support, and for providing me with an opportunity to explore the things I am most passionate about. Thank you to my committee members, Eric Dubow, Anne Gordon, and Paul Johnson. Your thoughtful feedback and interest in this project has helped to make it more scientifically sound, and "real-world" applicable. Thank you to my peers who have eagerly volunteered to proofread and edit this manuscript: Kelly Amrhein, Morgan Dynes, and Tony Bonadio - I feel blessed to have had peers of your intellectual caliber and sharp humor accompany me on this journey. I would also like to thank my parents and siblings, Pat, Greg, Juli, Katie and Michael, for the never-ending belief they had in my ideas and ability - although you had no clue what I was doing, you also knew "I could do it!" and for that, I'm forever grateful. My deepest gratitude and appreciation goes to my husband, Levi Lackey. Your steadfast love, support, and encouragement was my lifeboat throughout this process. Your faith in me while I worked towards my goals has been noticed and I am eternally grateful for that deepest kindness. Finally, I would like to thank the administrators, teachers, staff, and students from the districts discussed in this manuscript. Thank you for placing your trust in me, and for seeing the utility in this project. Research like this is never possible without the foresight of great community partners like you. 


\section{TABLE OF CONTENTS}

Page

CHAPTER I. INTRODUCTION ....................................................................... 1

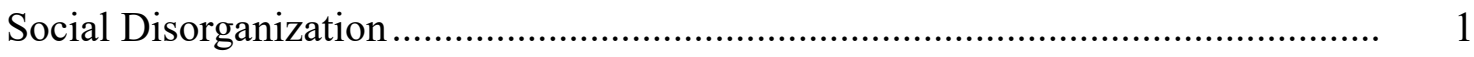

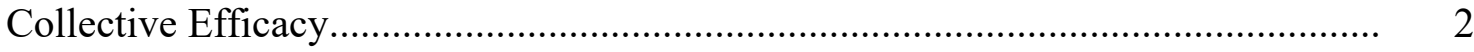

Schools as Communities .......................................................................... 3

Collective Efficacy in Rural Areas ............................................................... 7

Collective Efficacy in Rural Schools: An Alternative Model ................................ 9

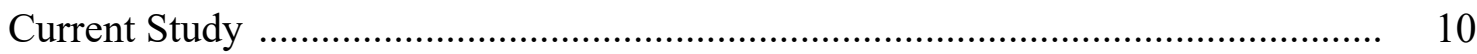

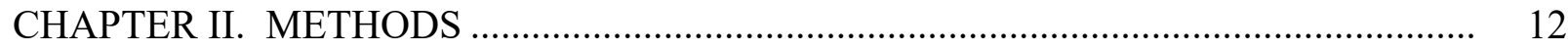

Sample and Procedure ............................................................................ 12

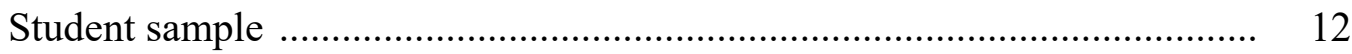

Teachers, staff, administrator sample ............................................. 13

Participants ............................................................................ 14

Student demographics .................................................................. 14

Teachers, staff, administrator demographics ..................................... 14

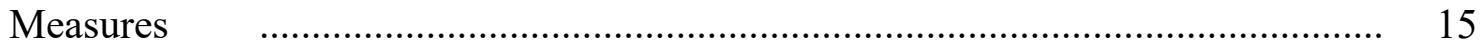

Student perceptions of neighborhood collective efficacy $\ldots \ldots \ldots \ldots \ldots \ldots \ldots \ldots \ldots . . . \ldots \ldots$

Student perceptions of school collective efficacy................................... 16

Students self-reported delinquency ................................................ 17

Connectedness to school .................................................................... 18

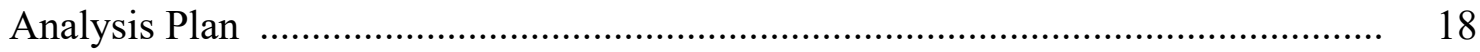

CHAPTER III. RESULTS ............................................................................... 20 
Missing Data and Outliers .............................................................................. 20

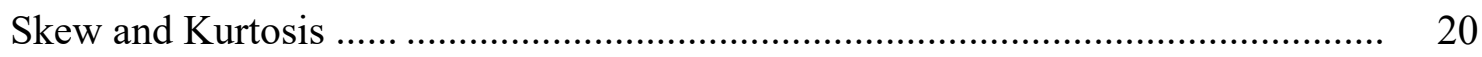

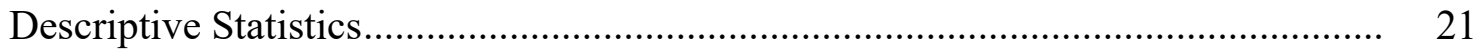

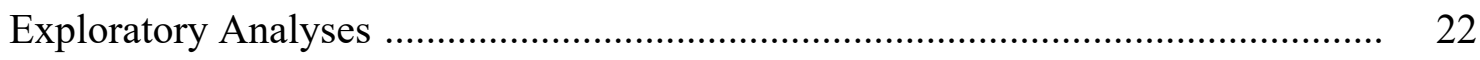

Bivariate correlations.................................................................. 22

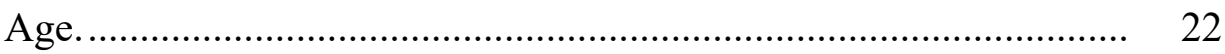

Connectedness to school........................................................ 22

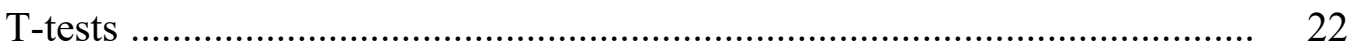

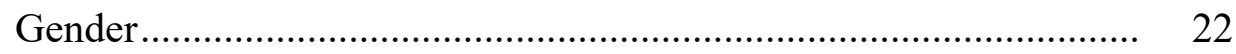

School membership.......................................................... 23

Race........................................................................... 24

Hypothesis 1: School-level Collective Efficacy .............................................. 24

Hypothesis 2: Associations Between In-school and Out-of-school Delinquency ..... 24

Exploratory factor analyses of delinquency items ............................... 30

Hypothesis 3: Associations Between School and Neighborhood Collective

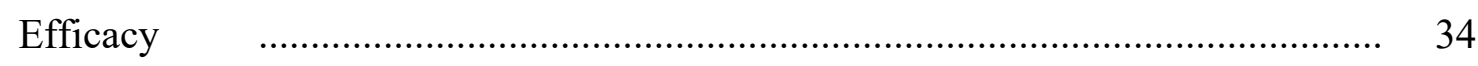

Hypothesis 4: Associations Between School Collective Efficacy and

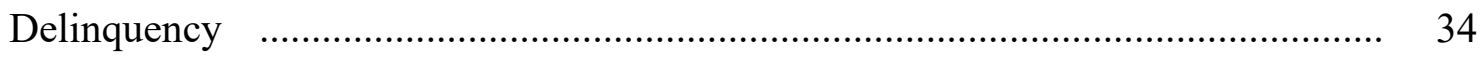

Regression examining collective efficacy .......................................... 35

Moderated regression examining connectedness .................................. 36

Teacher, Staff, Administrator Exploratory Analyses...................................... 37

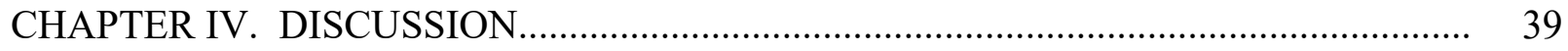

Examining School-Level Collective Efficacy ............................................... 40 
Neighborhood vs. School Collective Efficacy............................................... 40

Self-Reported Delinquency...................................................................... 42

Regression Analyses of School Collective Efficacy and Delinquency .................... 42

Strengths and Limitations ..................................................................... 44

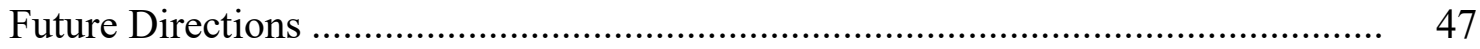

Conclusions and Practical Applications...................................................... 48

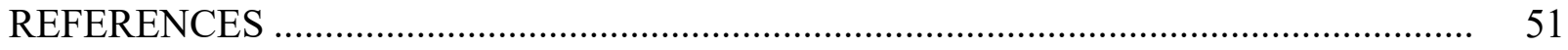

APPENDIX A. PARENT CONSENT LETTER ......................................................... 56

APPENDIX B. STUDENT ASSENT LETTER ....................................................... 58

APPENDIX C. TEACHER/STAFF/ADMINISTRATOR RECRUITMENT LETTER ...... $\quad 60$

APPENDIX D. TEACHER/STAFF/ADMINISTRATOR SURVEY ............................ 61

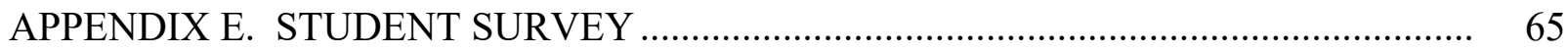

APPENDIX F. HSRB APPROVAL LETTER ..................................................... 78 


\section{LIST OF FIGURES}

Figure

1 School Collective Efficacy Model...
Page

11 


\section{LIST OF TABLES}

Table $\quad$ Page

$1 \quad$ Means and Standard Deviations for Students ............................................... 21

2 Frequencies, Means, Medians, and Ranges for Delinquency Items ................. 26

3 Rotated Pattern Matrix from Exploratory Factor Analysis of Youth-Reported

Delinquency Scale, Restricted to Six Factors ........................................... 31

4 Summary of Hierarchical Regression Analysis for Collective Efficacy

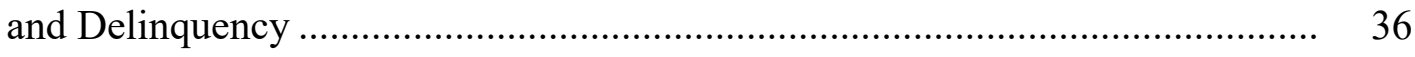

$5 \quad$ Teachers vs. Students Means for Variables of Interest................................... 38 


\section{CHAPTER I. INTRODUCTION}

A number of social contexts, such as school context, family context, peer group, and neighborhoods, have been identified as having significant impacts on adolescent development and growth (Bronfenbrenner, 1986). Models of neighborhood influence, traditionally based on dense urban neighborhoods, have been repeatedly shown to have a significant influence on delinquency in particular. However, these same models of neighborhood influence have been shown to poorly generalize to rural areas (Barnett \& Mencken, 2002; Bouffard \& Muftić, 2006; Domoff, Hayman, \& Tompsett, 2012; Osgood \& Chambers, 2000; Wells \& Weisheit, 2004; Witherspoon \& Ennett, 2011). Given that one-fifth of the nation's population resides in rural areas (United States Census Bureau, 2012), and that rural crime is increasing (National Gang Intelligence Center, 2009), with some crimes, like sexual assault, actually being more prevalent in rural areas compared to urban and suburban areas (National Crime Victimization Survey, 2014), a better model is needed of community influence on juvenile delinquency in rural areas. Social Disorganization

One of the most influential models of community-level predictors of crime is Shaw and McKay’s social disorganization theory (1942). Shaw and McKay first observed that crime, including juvenile delinquency, was more concentrated in some urban neighborhoods than others, and suggested that neighborhoods with higher rates of crime are qualitatively different than those with lower rates of crime. Shaw and McKay identified several neighborhood characteristics that were associated with crime including residential instability, poverty, ethnic heterogeneity, and proportion of single-parent households. Shaw and McKay (1942) suggested that communities high in residential instability, poverty, ethnic heterogeneity, and single-parent households are less likely to share communal values or beliefs, which they posited would result 
in higher rates of delinquency and crime. Witherspoon and Ennett (2011) found similar results over half a century later, adding further support to the idea that communities with high levels of the aforementioned structural characteristics have high rates of delinquency and crime.

\section{Collective Efficacy}

Sampson and colleagues (1997) extended the social disorganization model by integrating the construct of collective efficacy, a neighborhood-level social construct that links demographic characteristics of neighborhoods with crime (Sampson, Raudenbush, \& Earls, 1997). Collective efficacy is comprised of two components: social cohesion, defined as the mutual trust shared by neighborhood residents, and informal social control, defined as the shared willingness of residents to intervene for the common good of the neighborhood. Strong neighborhood social cohesion facilitates communication between neighbors, increases agreement on shared norms or values, and can lead to greater informal social control. In more traditional formal social control, institutions such as courts, police departments, and schools, take the responsibility to impose control and attempt to regulate the behavior of group members in the form of policy making, policy practices, and local legislation. By contrast, informal social control can reduce crime as neighbors come together to take action themselves.

In the context of Shaw and McKay's social disorganization theory, Sampson and colleagues suggested that lower neighborhood collective efficacy would result from the demographic characteristics associated with high levels of social disorganization, such as residential instability, poverty, ethnic heterogeneity, and single-parent households (Sampson et al., 1997). In communities high in these characteristics, Sampson argued that neighbors would be less willing to exercise informal social control because these characteristics make it less likely that residents would share common goals and values, thus weakening neighborhood social 
cohesion. He also suggested that, in these less cohesive neighborhoods, residents may be less likely to intervene for the common good, as they lack a sense of responsibility to their fellow neighbors (Sampson et al., 1997) ultimately resulting in higher levels of crime and delinquency. Both Sampson and other researchers have found consistent support for the importance of neighborhood collective efficacy in explaining juvenile delinquency (Browning \& Jackson, 2013; Duncan, T. E., Duncan, Okut, Strycker, \& Hix-Small, 2003; Leventhal \& Brooks-Gunn, 2000; Mazerolle, Wickes, \& McBroom, 2010).

\section{Schools as Communities}

Studies of social disorganization and collective efficacy have clearly established the importance of the neighborhood context in ecological models of juvenile delinquency in urban areas. However, schools also function as an important context which shape the development of children, and research on characteristics of the school setting is growing. Schools are a primary social context for youth (Battistich \& Hom, 1997) which are likely the first site of peer socialization for children and are the principal settings in which children first encounter peer influences, structure, and collective environmental effects. Understanding the impact of schoollevel effects is particularly important given the growing amount of resources devoted to schoolbased prevention and intervention programs. Recently, there has been an increase in research adapting constructs developed in neighborhood research to the school setting, opening the door to a more nuanced understanding of the ways in which schools function as contexts shaping behavior, especially within rural areas, where schools may play the role of neighborhood.

A number of school-level constructs have been linked to both in-school and out-of-school problem behaviors, with many of these school-level variables appearing analogous to neighborhood-level processes. The first step in examining school-level variables that may be 
analogous to neighborhood-level processes is to determine that the school setting is experienced by students as an environment similar to a broader community. In that vein, studies of student perceptions of the school as a community have shown that, indeed this phenomenon occurs and that it impacts a number of outcomes. Specifically, past studies have shown that students who perceive their schools as communities feel more emotionally connected to their peers, teachers, and school, which is associated with fewer school-based problem behaviors (Battistich \& Hom, 1997; Demanet \& Van Houtte, 2012), with many of these studies also examining the quality of the perceived school community. Students that perceive their school as a supportive community demonstrate fewer self-reported problem behaviors, higher academic achievement, less absenteeism, and report greater enjoyment of school (Battistich \& Hom, 1997; Battistich, Solomon, Kim, Watson, \& Schaps, 1995; McMillan \& Chavis, 1986). Importantly, these studies primarily examine students' perceptions of schools, but offer little insight into the degree to which students' perceptions of their school match the "reality" of the school environment.

Another influential school-level variable is school climate, defined as "the shared beliefs, values, and attitudes that shape interactions between the students, teachers, and administrators" within a school (Anderson, 1982; Mitchell, Bradshaw, \& Leaf, 2010; Haynes, Emmons, \& BenAvie, 1997). Similar to neighborhood collective efficacy, school climate places emphasis on the importance of shared values and is positively associated with academic achievement and reduced disruptive behavior in a classroom (Haynes et al., 1997). Unlike neighborhood-level collective efficacy, school climate has been conceptualized as a broad term that encompasses more specific school-level variables including school culture, organization and structure, and social milieu (Anderson, 1982; Stewart, 2003), Additionally, social disorganization and physical disorganization, variables similar to Shaw and McKay's (1942) social disorganization construct, 
have been broadly applied to the study of the school environment. School-level characteristics associated with disorganization, such as teacher/staff turnover and student turnover, have been negatively associated with perceptions of school climate (Plank, Bradshaw, \& Young, 2009).

While a number of other community-level variables can and have been applied at the school level, the current study focused on a particular community construct that has been researched most commonly in relation to delinquency or problem behaviors: collective efficacy, which is comprised of the subscales of informal social control and social cohesion. Not only was collective efficacy selected for this study due to literature consistently linking neighborhood collective efficacy to juvenile delinquency, but in terms of assessment, the most commonly used measure of neighborhood collective efficacy can be translated easily from a neighborhood setting to a school setting (Williams \& Guerra, 2011). Future studies may choose to parse out distinctions between the constructs of school climate and school collective efficacy (in particular, school-level social cohesion), as measures of these constructs tend to share similar items. However, by choosing school-level variables that are assessed similarly to neighborhood level variables, and are conceptualized to represent the same construct in different contexts, the current study was able to focus on the comparison between neighborhoods and schools as influences on adolescent delinquent behaviors.

Schools are necessarily located within neighborhoods, and it could be expected that schools might share many of the same characteristics or risk factors with the neighborhoods in which they are located. However, not only has existing literature proposed that schools themselves act as communities, but some evidence also suggests that schools and neighborhoods have distinct influences on youth outcomes. Specifically, Kirk (2009) found that neighborhood measures of social control are very loosely related to school measures of social control, 
suggesting that neighborhoods high in disorganization, concentrated poverty, and lacking in the components of collective efficacy, often but not always house schools with similar deficits.

Additionally, Cook and colleagues indicated that social contexts such as schools and neighborhoods are only weakly correlated (Cook, Herman, Phillips, \& Settersten, 2002). He emphasized this point by noting that students could live in disorganized neighborhoods while attending a "good school" and vice versa. Based on these findings, Cook and colleagues concluded that neighborhood and school contexts exert separate but cumulative influences on youth outcomes (Cook et al., 2002).

The definitions of the most widely used school-level variables return to the idea that shared values and beliefs of group members are essential to creating a shared context. This is similar to Sampson's argument regarding the importance of social cohesion in establishing the shared connection and shared responsibility that facilitates informal social control. For these reasons, school-level collective efficacy, including the two underlying components, school-level social cohesion and school-level informal social control, are the primary school environmental variables examined in this investigation. Some researchers have explicitly applied Sampson's collective efficacy constructs and other school-level variables similar to Sampson's neighborhood variables, within a school setting. These parallel variables include school collective efficacy (Plank et al., 2009; Sapouna, 2010; Williams \& Guerra, 2011), school social control (Ellonen, 2008), and school social cohesion (Oder, 2005). These studies developed measures of school collective efficacy that closely resemble Sampson's original measure of neighborhood collective efficacy (Plank et al., 2009; Sapouna, 2010; Williams \& Guerra, 2011). Factor analyses on these pre-existing measures of school collective efficacy have yielded factors comparable to Sampson's social cohesion and informal social control, with informal social 
control within the school further broken down into two additional components: control by peers and control by adult groups (Williams \& Guerra, 2011), providing additional evidence of the validity of these constructs in the school setting. Both Sapouna (2010) and Williams and Guerra (2011) found a significant relationship between levels of school collective efficacy and bullying, with higher reports of collective efficacy related to fewer instances of bullying. However, these studies were primarily interested in determining how school-level collective efficacy would impact school-level behavior, and neither included any out-of-school outcomes, such as delinquency. Without examining out-of-school behaviors, it is unclear what, if any, impact school-level collective efficacy may have on adolescents' overall behavior.

\section{Collective Efficacy in Rural Areas}

Studies of neighborhood effects on delinquency have focused on urban neighborhoods since the earliest conceptualization of social disorganization (Shaw \& McKay, 1942). The construct of collective efficacy was developed using the Project on Human Development in Chicago Neighborhoods (PHDCN), a study of neighborhoods in the metropolitan Chicago area (Sampson et al. 1997). Similarly, the majority of later studies of collective efficacy also used urban samples (e.g., Duncan et al., 2003). Constructs developed in cities, such as collective efficacy, do not always yield similar patterns of findings in rural areas (Barnett \& Mencken, 2002; Wells \& Weisheit, 2004). Additionally, specific divergent findings found between rural and urban areas include the effects of community poverty (Bouffard \& Muftić, 2006; Odgers et al., 2009; Osgood \& Chambers, 2000), the definition of a construct of concentrated disadvantage

(Witherspoon \& Ennett, 2011), and the effects of ethnic heterogeneity (Domoff et al., 2012), further supporting the idea that urban constructs of social disorganization do not generalize well to rural populations. 
One potential reason for conflicting findings in research on rural neighborhood constructs is that there is great difficulty in actually defining the rural "neighborhood." In one literature review, Marco and Marco (2010) summarized five ways in which "neighborhood" has been operationalized in rural areas, noting that each approach to defining a rural community has advantages and disadvantages and is best suited for different research questions. Examples of operationalizing rural neighborhoods includes using census blocks, asking respondents to selfreport on the area they consider to be their neighborhood, and asking participants to consider their neighborhood to be everything within a certain mile radius. Self-reported neighborhoods were suggested by Marco and Marco (2010) to be best suited for research questions attempting to assess the role of a perceived influence of a neighborhood construct on outcomes. Even after operationalizing a rural area as a neighborhood, additional difficulties arise in obtaining the matching data for that neighborhood. For example, Marco and Marco (2010) and Roosa and colleagues (2009) noted that one primary issue of using self-reported neighborhoods as the operationalized definition of a participant's neighborhood is finding matching census-level variables (Roosa, White, Zeiders, \& Tein, 2009). It would be impossible to obtain census-level data unless the "self-reported" neighborhood lined up exactly with the predetermined census block, which is unlikely to occur. Overall, Marco and Marco (2010) strongly emphasized that urban-centric constructs like collective efficacy do not always translate well into rural communities, and that this discrepancy helps to explain why community research in rural areas does not always yield patterns of findings similar to existing urban studies, or yield similar patterns among different rural areas. 


\section{Collective Efficacy in Rural Schools: An Alternative Model}

It is apparent that neighborhood models developed in urban areas do not clearly generalize to rural areas, in large part due to difficulty defining the boundaries of rural "neighborhoods," but this poor generalizability is also likely due to the differences between rural and urban infrastructure, cultural norms, and access to resources. At the same time, schools often play a central role in rural communities, serving many functions in addition to providing education (for example, serving as sites for bridal showers, carnivals, or Friday night football games). It may be possible that schools function as a clearer "community"-level construct than do neighborhoods in rural areas; therefore, research examining community-level effects on youth may yield more consistent results in rural areas if the "community" is redefined around the school setting. Crosnoe (2004) offers one support of this suggestion, noting that schools not only act as a learning environment, but can also act as a social environment, providing students with chances to learn and interact socially. In rural areas, youth are likely to spend more time in school settings than in "neighborhood" settings. This is likely due to the fact that in many rural areas there are few to no other places, outside of the school and school functions, for adolescents to spend their time. Rural schools are often the site of both school-affiliated and non-school affiliated extracurricular programs and activities. This positions the school as an optimal site of influence on local youth. Also, unlike the ambiguous and vague definitions of "neighborhoods"

found in previous rural literature concerning these constructs, a school is a clearly defined social environment and contrasts the many definitions of "neighborhood" within a rural setting. For example, considering if a peer technically lives in one's "neighborhood" may be a challenging question for many rural youth, yet they can easily identify whether the same peer is or is not a student at their school. 
The primary argument examined in this study was that an alternative model of rural delinquency is possible following these three points as taken from the review of the literature above: schools have been shown to act as social environments similar to neighborhoods (Crosone, 2004), traditional neighborhoods can be difficult to conceptualize in rural areas (Marco \& Marco, 2010), and constructs developed in cities do not always yield similar patterns of findings in rural areas (Barnett \& Mencken, 2002; Bouffard \& Muftić, 2006; Domoff et al., 2012; Osgood \& Chambers, 2000; Wells \& Weisheit, 2004; Witherspoon \& Ennett, 2011).

These findings lead to the conclusion that in rural areas it is possible that school-level collective efficacy might be more strongly associated with both in-school and out-of-school problem behaviors than neighborhood-level collective efficacy. Previously established urban models of juvenile delinquency have been supported when applied to school settings. With that in mind, an investigation of the potential relationship between school-level variables and juvenile delinquency in rural areas was deemed necessary and conducted in the hope that it would offer clarity to the currently broad application of urban-centric neighborhood models to rural areas. This was based on one underlying assumption; in rural areas, schools may act in the same role as "neighborhoods" in Sampson's model of collective efficacy, while being more clearly defined and conceptualized than geographically determined rural neighborhoods.

\section{Current Study}

The objectives of this study were to conduct a preliminary investigation of the following constructs: student perceptions of rural neighborhood-level collective efficacy via informal social control and social cohesion, student perceptions of school-level collective efficacy via informal social control and social cohesion, and teacher/staff perceptions of school-level informal social control and social cohesion. This study contributed to the existing literature on rural delinquency 
by investigating whether school-level collective efficacy was more closely related to selfreported delinquency than neighborhood- level collective efficacy. Four main hypotheses were made:

1. The construct of school collective efficacy would be supported by student reports, with positively correlated subscales of school social cohesion and school social control.

2. Perceived school collective efficacy would be inversely correlated with both in-school and out-of-school self-reported delinquency.

3. School-level collective efficacy and neighborhood-level collective efficacy would comprise related but independent constructs, correlating at $\mathrm{r} \leq .50$.

4. School-level collective efficacy would be more strongly associated with both inschool and out-of-school delinquency when compared to perceptions of neighborhoodlevel collective efficacy (Figure 1).

Figure 1. School Collective Efficacy Model

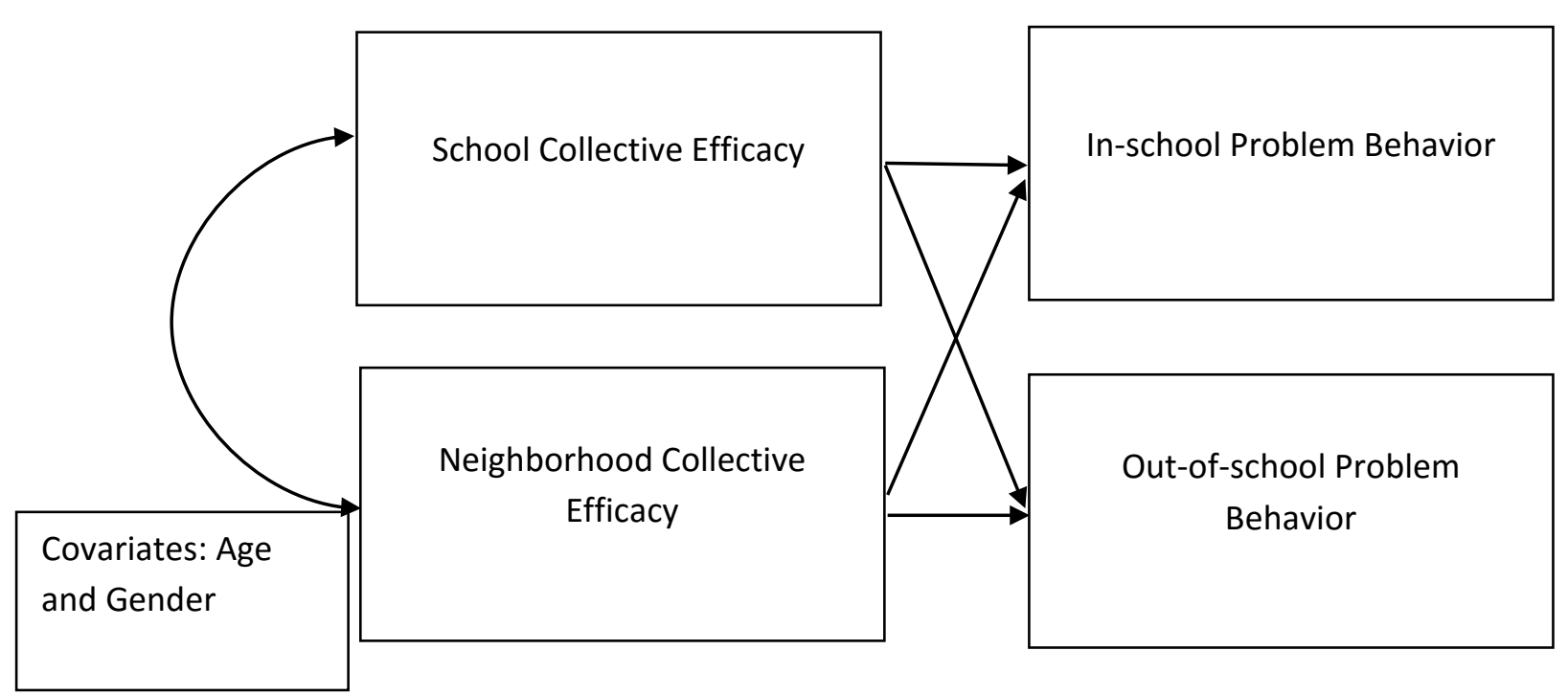




\section{CHAPTER II. METHODS}

\section{Sample and Procedure}

Student sample. Eleven total school districts were contacted regarding their interest in participating in the study. Of the eleven districts contacted, nine were located in Ohio and identified by the Ohio Department of Education (ODE) as belonging to the "rural typology" category. ODE described this "rural typology" as districts with "high student poverty, and small student population" (Ohio Department of Education, 2015). The other two districts were located in southern Arkansas and northern Louisiana. These schools were identified as "rural" by local community contacts but no state level designations could be located. Of the eleven total districts contacted, two southeast Ohio districts agreed to participate (henceforth referred to as "District A" and "District B"); each were located in two of the 27 Federally designated "Appalachian" counties in Ohio, and located roughly 20 miles from one another. Also, both districts had one central school building for seventh through twelfth grade.

Parents of potential participants were contacted through a consent letter sent home from school with adolescents (Appendix A). These consent letters were given to school staff, and then passed to teachers located in classrooms in which data collection would be conducted. Teachers then distributed the letters to their students. Per school administrators, sending letters home with students was consistent with how the schools typically communicated with parents. Consent forms were to be returned to the adolescents' school if the parents did not want their child to participate. Parents of potential participants were given two weeks to return the consent forms if they did not want their child to participate. Researchers provided a copy of the survey to be left at the schools for parents to view prior to returning the consent form. Of the approximately 350 students whose parents were sent letters, only three parent consent forms, two letters from 
District A and one letter from District B, were returned indicating that parents did not authorize for their children to participate. Adolescents with parent permission were asked for their assent prior to the distribution of the surveys. Potential participants were provided with a letter outlining their confidentiality (Appendix B) which was also explained verbally. Prior to providing their assent, participants were given the opportunity to ask researchers and teachers about the study, along with the nature of their confidentiality.

Those participants who provided assent were then given a hard copy of the survey and allowed to read through and answer questions at their own pace in a classroom setting. During the course of data collection, five students, two from District A and three from District B, opted not to complete the survey and were given an activity to complete by their teacher while their classmates completed the survey. Adolescents were encouraged to ask the researcher to explain any questions and/or wording they did not fully understand. After completion, surveys were placed into manila envelopes and transported to the researcher's office in Arkansas for data entry and analysis where they were stored in a locked file cabinet in the researcher's locked agency office.

Teachers, staff, administrator sample. On the day that student surveys were collected, recruitment letters (Appendix C) and teacher/staff/administrator surveys (Appendix D) were made available in the main office, teachers' lounge, and in the classrooms in which student data was collected. Unlike students, teachers were not read the consent letter, but rather were provided the letter and allowed to read over it, and then consent or decline their invitation to participate in the survey. Similar to student surveys, teachers, staff, and administrators were encouraged to ask questions they may have about the survey, and especially about the confidentiality of their responses. Teachers, staff, and administrators completed surveys at their 
convenience throughout the day of student data collection at their school. Upon completion, most teachers, staff, and/or administrators walked to the room in which student data was being collected and turned in their completed survey. The primary investigator also walked to several teachers' rooms to collect the completed survey at the end of the academic day, per several teachers' request. Completed surveys were also placed in a manila envelope and transported with student surveys for data entry and analysis to the researcher's office in Arkansas. There, they were stored in a locked file cabinet in the researcher's locked agency office.

Participants. A total of 361 surveys were collected from two schools; 28 were completed by teachers, staff, or administrators, and the remaining 333 were completed by junior and senior high students.

Student demographics. The majority of respondents were ninth graders $(32.6 \%)$, followed by tenth graders $(28.8 \%)$, eighth graders $(9.9 \%)$, seventh graders $(8.0 \%)$, eleventh graders $(8.0 \%)$, twelfth graders $(7.0 \%)$, and 18 students did not indicate a grade $(5.8 \%)$. The reported gender of respondents was nearly evenly split between female (48.2\%) and male (44.1\%), while a small portion indicated that they either identified as a gender "other" than "man and woman" or indicated that they "preferred not to answer" $(2.0 \%)$. A few students $(5.8 \%)$ did not indicate their gender at all. Consistent with the demographics of rural Ohio, the large majority of the respondents were White (85.9\%). There was little racial diversity with a small portion reporting to be Other (4.5\%), Black (4.2\%), Native American (1.9\%), Asian (.6\%), and Hispanic (.3\%). Only eight respondents $(2.6 \%)$ did not indicate their race.

Teacher, staff, administrator demographics. Most teachers sampled taught classes that spanned one or more high school grades $(28.6 \%)$, with nearly one fifth $(17.9 \%)$ teaching all grades seventh through twelfth. A small portion of teachers reported to solely teach only students 
in a specific grade (eighth and ninth; 7.1\% each), while a similar percentage reported to teach classes to both junior high grades $(7.1 \%)$, and only one teacher reported to teach only classes to eleventh grade students (3.6\%). Over a quarter of responding teachers, staff, and/or administrators chose not to complete the item (28.6\%). The majority of respondents were female (57.1\%), and White (96.4\%), with one respondent indicating “Asian or Pacific Islander" heritage $(3.6 \%)$.

\section{Measures}

Student perceptions of neighborhood collective efficacy. Based on the seminal study by Sampson et al. (1997), five items were used to assess perceptions of neighborhood informal social control and social cohesion (Appendix E, Section 1). Consistent with one operational definition outlined by Marco and Marco (2010), students were asked to report on their selfdefined neighborhood and researchers did not prompt them on how to think about "their neighborhood." Several students asked the question "What if I don't live in a neighborhood?" and were instructed to answer the questions based on "Whatever they consider to be their neighborhood." Marco and Marco (2010) noted that self-defined neighborhoods adhere more closely to the neighborhood as a construct and thus more accurately estimates neighborhood effects on residents. Each item was assessed on a five-point scale $(1=$ very likely, $2=$ likely, $3=$ neither likely nor unlikely, 4 = unlikely, 5 = very unlikely), which were recoded on a 0-4 scale for analyses. These items were used to assess the participants' perceptions of the likelihood that neighbors would intervene if they witnessed delinquent behaviors taking place in their neighborhood (e.g., "If a group of neighborhood teens were skipping school and hanging on a street corner, how likely is it that your neighbors would do something about it," "If there was a fight in front of your house and someone was being beaten or threatened, how likely is it that 
your neighbors would break it up"). Similar to social control, to assess perceptions of neighborhood social cohesion, participants rated, using a five-point scale $(1=$ strongly disagree, $2=$ disagree, $3=$ neither agree nor disagree, $4=$ agree, $5=$ strongly agree), how strongly they agreed with statements made about their neighborhood (e.g., "People around my neighborhood are willing to help their neighbors," "My neighborhood is close-knit," (Sampson et al., 1997, p. 920)). Prior to creating a composite score for neighborhood collective efficacy, the means were found for each subscale. Reliability was acceptable for both neighborhood social control $(\alpha=74)$ and neighborhood social cohesion $(\alpha=72)$. The means of the neighborhood social control and the neighborhood social cohesion subscales were used to create the neighborhood collective efficacy total scale.

Student perceptions of school collective efficacy. School collective efficacy was measured by assessing the two constructs (informal social control and social cohesion) that create collective efficacy in the school setting. A modified version of Sampson's neighborhood social cohesion scale was used to assess perceptions of school collective efficacy (Williams \& Guerra, 2011). Seven items (Appendix E, Section 2), each assessed on a four-point Likert-type scale $(1=$ really disagree, $2=$ disagree, $3=$ agree, $4=$ really agree $)$, were used to assess perceptions of school-level social cohesion. This measure of school social cohesion was based on Sampson's measure of neighborhood social cohesion, modified for a study of bullying in schools.

Informal social control was operationalized as the willingness of students and teachers to intervene in situations, including bullying. Similar to the measure of neighborhood level informal social control, participants were asked to think about the likelihood of students or teachers intervening in four different situations. Each situation was asked separately about students and 
teachers, resulting in eight items for the informal social control index. Each item was assessed on a five-point scale $(1=$ very likely, $2=$ likely, $3=$ neither likely nor unlikely, $4=$ unlikely, $5=$ very unlikely). Internal consistency of the items that comprise school collective efficacy were acceptable for both composite variables in the scale (school social control $\alpha=.78$, school social cohesion $\alpha=$.77). The total school collective efficacy scale was created first by weighting the school social cohesion mean to transform it to a 5-point scale, then by taking the mean of the weighted school social cohesion and school social control scales.

Students' self-reported delinquency. Self-reported delinquency was assessed using a 37-item measure. The first 23 of these items were taken from the first wave of the National Youth Survey, a longitudinal study conducted from 1976 to 1987 including a total of 1,725 participants (Appendix E, Section 4; Elliot et al., 1996). Items were answered on a 9-point Likert-type scale ranging from $0=$ Never, $4=$ Once every 2-3 weeks, to $8=2-3$ times a day. Items begin with the phrase "During the past year, how many times have you...". Sample items include “...stolen or tried to steal money or something worth $\$ 100$ or more?”, “...threatened someone with a weapon?”, and “...been involved in gang fights?” In addition to the 23 items that make up this established self-reported delinquency measure, additional items were re-worded and added as appropriate to assess if these behaviors occurred inside or outside of the school setting. Also, eight new items were added in an effort to include additional forms of delinquency that may be more common among rural youth. These items were generated by the author based on anecdotal experience gathered while conducting research and working clinically with rural populations. This resulted in a delinquency measure with 37 total items.

A total delinquency count was calculated by dichotomizing all delinquency items $0=$ Not within the past year, $1=$ Within thin the past year. The sum of these dichotomized items resulted 
in a count variable ranging from $0-37$ with high internal consistency $(\alpha=.93)$. Although the items are measured on a frequency scale, it is most common for this scale to be analyzed as a variety count (Elliott et al., 1996). More information on alternative operationalizations of delinquency are discussed in the RESULTS section.

Connectedness to school. Prior to exploratory analyses using the four connectedness to school items, items from this scale were appropriately reverse coded and then, consistent with how items have been examined in the past (Demanet \& Van Houtte, 2012), were computed into a composite variable composed of the sum of all items on this scale. Internal consistency of these items was acceptable $(\alpha=.77)$.

\section{Analysis Plan}

Following an examination of missing data and data cleaning, means and standard deviations were calculated for all variables of interest. Correlation analyses and t-tests were conducted to examine the relationship between potential covariates of age, gender, school membership, race, and connectedness to school to the dependent and independent variables.

To test Hypothesis 1, correlational analyses were run between school-level informal social control and social cohesion. Informal social control and social cohesion were initially examined independently, primarily to establish their reliability within this sample. These variables were also initially examined independently so that it could be established that informal social control and social cohesion were both independently present in a school setting, a setting in which they are not traditionally studied. Once it was determined that these variables were independent of one another, yet related to one another and outcome variables as expected, later analyses combined informal social control and social cohesion from both neighborhood and 
school settings in order to investigate conclusions about neighborhood- and school-level collective efficacy.

To test Hypothesis 2, the best representation of the delinquency construct for this sample had to be established. Reliability statistics and exploratory factor analyses were used to find the best representation of delinquency, which was then included in correlational analyses with school-level collective efficacy. Similarly, to test Hypothesis 3, neighborhood-level and schoollevel collective efficacy were included in correlational analyses.

Initially, a path analysis was proposed to test Hypothesis 4, however, after the aforementioned analyses were conducted, the proposed path analyses was no longer appropriate, and a hierarchical linear regression was used instead. 


\section{CHAPTER III. RESULTS}

\section{Missing Data and Outliers}

Of the 333 student surveys collected, eight entire surveys were removed from analyses because they failed to complete large portions of the survey including demographic information. The 325 remaining student surveys were examined for outliers. An additional twelve surveys were removed during the data cleaning phase because it appeared that these respondents circled items that were the "worst" for every item, including two based on the school informal social control scale, two based on the school social cohesion scale, and eight based on the delinquency scale.

Of the 313 surveys remaining, 50 were missing values in variables used to compile composite scores: neighborhood social cohesion, neighborhood social control, school social cohesion, school social control, and total delinquency. A within-subject average for each scale missing less than $25 \%$ of items was generated and then that individualized value was used to replace the missing value $(n=50)$. This resulted in an $N=313$ of student surveys that were used

for many subsequent analyses. However, of those 313, multiple students did not respond to items assessing some demographic variables such as age, race, gender, and others. As a result, the analyses that include demographic variables have varying $N \mathrm{~s}$.

\section{Skew and Kurtosis}

An examination of the items making up neighborhood informal social control and neighborhood social cohesion did not reveal any outliers, or any obvious patterns in responding, but both did demonstrate skewed distributions. Both variables were log transformed, however, this $\log$ transformation resulted in a larger skew (10.29 and 8.45 respectively) and thus the $\log$ transformed variables were not used for subsequent analyses. 
The school informal social control scale was found to be both skewed and kurtotic in distribution. A log transformation was completed and again the log transformation resulted in larger skew (log transformed skew $=13.23)$, and the $\log$ transformed variable was not used in subsequent analyses. However, neither skew nor kurtosis was found to be significant for school social cohesion.

The total delinquency scale demonstrated significant positive skew and kurtosis. Log transformation markedly improved skew ( $\log$ transformed skew $=.705$, kurtosis $=-.467)$, so the transformed variable was used in later analyses.

\section{Descriptive Statistics}

Mean scores and standard deviations for variables of interested are located in Table 1. Notably, the mean score for the total delinquency scale $(M=1.56)$ suggested that on average, students in this sample had a very low level of delinquent engagement over the past year.

Table 1

Means and Standard Deviations for Students

\begin{tabular}{lccc}
\hline Variable & $N$ & $M$ & $S D$ \\
\hline Total delinquency (0-15) & 313 & 1.56 & 2.30 \\
Neighborhood collective efficacy (1-5) & 313 & 3.41 & .60 \\
Neighborhood Informal Social Control (1-5) & 313 & 3.39 & .78 \\
$\quad$ Neighborhood Social Cohesion (1-5) & 313 & 3.43 & .67 \\
School collective efficacy (1-5) & 313 & 3.54 & .50 \\
$\quad$ School Informal Social Control (1-5) & 313 & 3.73 & .60 \\
School Social Cohesion (1-4) & 313 & 3.34 & .58 \\
Connectedness to School (7-20) & 308 & 16.55 & 3.71
\end{tabular}




\section{Exploratory Analyses}

\section{Bivariate correlations.}

Age. Correlation analyses were run with the age variable and total delinquency scale and revealed that age was significantly associated with students' self-reported delinquency $(r=.16, p$ $<.01)$.

Correlation analyses were also run with age, and both school, and neighborhood, informal social control and social cohesion. Age was not a significant predictor of student perceived informal social control (neighborhood $r=-.05, p=.34$; school $r=-.052, p=.372$ ) or social cohesion (neighborhood $r=-.01, p=.835$; school $r=-.08, p=.15$ ) in either setting.

Connectedness to school. Correlation analyses revealed that student reported connectedness to school was significantly negatively correlated to delinquency $(r=-.20, p<$ $.01)$. Those respondents that reported a greater connectedness to their school reported lower levels of delinquency.

\section{$T$-test.}

Gender. $T$-tests were conducted to examine if there were significant mean differences by gender of student on the total delinquency variable. No significant differences were found by student gender on delinquency $(t(287)=1.81, p=.07)$ such that males $(M=1.72, S D=2.35)$ exhibited no higher levels of delinquency than females $(M=1.30, S D=2.12)$. As such, youth gender was not included in subsequent regression analyses.

Gender was also examined to determine differences on neighborhood informal social control, neighborhood social cohesion, school informal social control, and school social cohesion. There were no significant mean differences by gender on the neighborhood informal social control variable $(t(287)=-.04, p=.97)$ such that males $(M=3.43, S D=.79)$ exhibited no 
higher levels of delinquency compared to females $(M=3.44, S D=.75)$. Similarly, there were no significant mean differences by gender on the neighborhood social cohesion variable $(t(287)=$ $.41, p=.68)$ such that males $(M=3.47, S D=.65)$ exhibited no significant differences in the levels of delinquency compared to females $(M=3.44, S D=.64)$. Also, neither school informal social control $(t(287)=.30, p=.76)$ nor school social cohesion $(t(287)=-.95, p=.34)$ demonstrated any mean differences in the levels of delinquency by gender.

School membership. T-tests were conducted to examine if there were significant mean differences by school student attended on the total delinquency variable. No significant differences were found by student school membership on delinquency $(t(311)=.74, p=.46)$, with students attending District A $(M=1.62, S D=2.31)$ reporting roughly the same level of delinquency as students attending District B $(M=1.47, S D=2.29)$.

School student attended was also examined to determine differences on neighborhood informal social control, neighborhood social cohesion, school informal social control, and school social cohesion. There were significant mean differences by school student attended on the mean neighborhood social cohesion variable $(t(311)=-3.51, p<.001)$, with students attending District A $(M=3.32, S D=.67)$ reporting significantly lower levels of neighborhood social cohesion compared to students attending District B $(M=3.59, S D=.65)$. There were also significant mean differences by school student attended on the mean neighborhood informal social control variable $(t(311)=-2.87, p<.01)$, with students attending District $\mathrm{A}(M=3.29, S D=.80)$ reporting significantly lower levels of neighborhood informal social control compared to students attending District B $(M=3.55, S D=.72)$.

In terms of school informal social control, no significant differences were found by student school membership $(t(311)=-.86, p=.39)$, with students attending District A $(M=3.71$, 
$S D=.59)$ reporting roughly the same level of delinquency as students attending District $\mathrm{B}(M=$ 3.77, $S D=.63)$. There were, however, significant mean differences by school student attended on the mean school social cohesion variable $(t(311)=-4.31, p<.001)$, with students attending District A reporting significantly lower levels of school social cohesion $(M=3.24, S D=.58)$ compared to students attending District B $(M=3.52, S D=.53)$.

Race. Regarding race, similar to the racial makeup of the geographical area, most student respondents identified as White, with very few endorsing any other race. Given this low sample for non-White respondents, t-tests to examine racial different between White and non-White respondents were used, rather than ANOVA analyses using small samples for all other races. There were significant mean differences by the dichotomized race variable $(t(303)=-2.49, p=$ $.01)$, with White students reporting $(M=1.41, S D=2.11$ significantly lower levels of delinquency compared to non-White students $(M=2.50, S D=3.10)$.

\section{Hypothesis 1: School-level Collective Efficacy}

Correlations were utilized to test Hypothesis 1, predicting that school informal social control and school social cohesion would be positively correlated. As predicted, the subscales were found to be significantly positively correlated to one another $(r=.45, p<.01)$. Although the two variables were highly correlated, the correlation coefficient was not above .50, suggesting that these are separate but related constructs.

\section{Hypothesis 2: Associations Between In-school and Out-of-school Delinquency}

Frequency analyses were run for all items on the delinquency measure, including the “rural delinquency" items added to Elliott's delinquency measure, to better understand potential differences between in-school and out-of-school delinquency. Table 2 contains frequencies, ranges, means, and medians for all 37 delinquency items. As expected, a large portion of 
respondents reported to have never engaged in a single delinquent behavior over the past year (21.4\%). At the item level, only one item was endorsed by more than $50 \%$ of respondents as a behavior they had engaged in within the past year ("At SCHOOL, cheated or copied someone else's work on an assignment, quiz, or test for a class?”; mean $=59.4 \%$ ). 
Table 2

Frequencies, Means, Medians, and Ranges for Delinquency Items

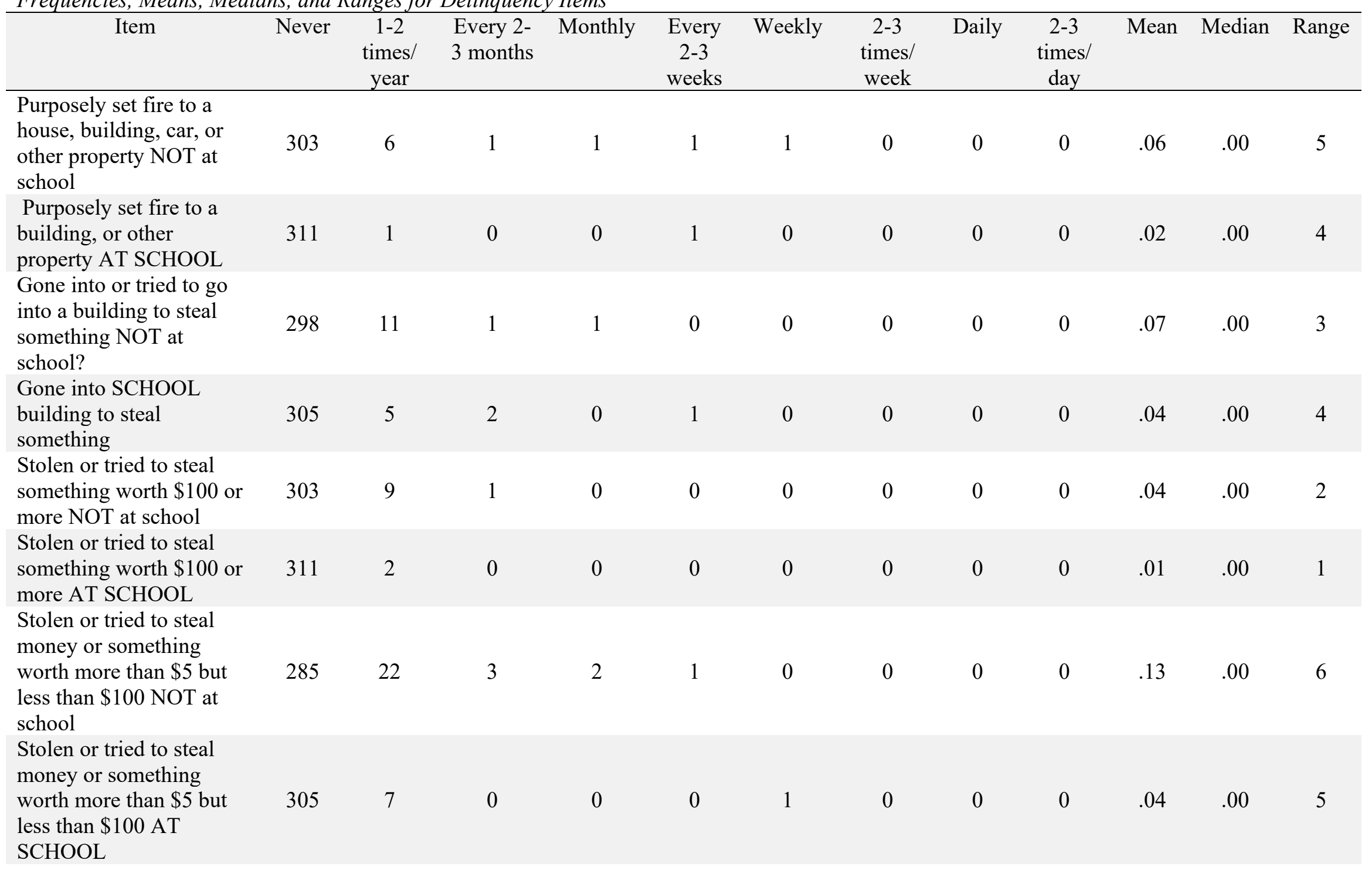


Stolen or tried to steal money or things worth $\$$ 275 29

4

1

2

1

1

0

0

.19

.00

6

Stolen or tried to steal money or things worth or less AT SCHOOL

Knowingly buy, sell, or

hold stoler

school?

Knowingly buy, sell, or

hold stolen goods WHILE

297

0

1

$0 \quad 0$

0

10

.06

$.00 \quad 7$

\section{AT SCHOOL}

Snatched someone's

purse or wallet or picked someone's pocket while 307

$17 \quad 5$

5

$1 \quad 130$

0

0

0

1

.13

.00

8

NOT at school

Snatched someone's

purse or wallet or picked

someone's pocket

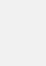

1

1

WHILE AT SCHOOL or
a SCHOOL FUNCTION?

Stolen or tried to steal a

motor vehicle

Carried a hidden weapon

NOT at school?

Carried a hidden weapon

WHILE AT SCHOOL

While NOT at school,

attacked someone with a

weapon

Attacked someone with a

weapon AT SCHOOL

While NOT at school,

used a weapon, force, or

strong-armed methods to

$\begin{array}{lllllllllllll}312 & 1 & 0 & 0 & 0 & 0 & 0 & 0 & 0 & .00 & .00 & 1 \\ 199 & 27 & 5 & 10 & 5 & 3 & 10 & 17 & 37 & 1.84 & .00 & 8 \\ 276 & 20 & 7 & 3 & 1 & 0 & 0 & 4 & 2 & .30 & .00 & 8 \\ 297 & 10 & 4 & 0 & 0 & 1 & 0 & 0 & 1 & .10 & .00 & 8 \\ 304 & 6 & 0 & 1 & 0 & 1 & 1 & 0 & 0 & .06 & .00 & 6 \\ 311 & 2 & 0 & 0 & 0 & 0 & 0 & 0 & 0 & .01 & .00 & 1\end{array}$


take money or things

from people

Used a weapon, force, or strong-armed methods to take money or things

from people at SCHOOL

Sold or dealt drugs or

prescription medications

NOT at school

310

(2)

292

9

3

3

Sold or dealt drugs or prescription medications

302

\section{AT SCHOOL}

Been paid for sexual relations

$\begin{array}{ll}7 & 0 \\ 2 & 1\end{array}$

Had or tried to have

sexual relations with someone against his or

306

\section{her will}

Been involved in a gang

fight NOT at school

Been involved in a gang

fight AT SCHOOL

306

Driven a vehicle while under the influence of alcohol or drugs

Hit one of your parents or another relative

While NOT at school, hit someone other than a

relative out of school

Hit someone other than a relative AT SCHOOL

Trespassed onto someone else's property or broken into a building NOT at school

\begin{tabular}{|c|c|c|c|c|c|c|c|c|c|c|c|}
\hline 300 & 7 & 2 & 3 & 0 & 0 & 0 & 0 & 1 & .09 & .00 & 8 \\
\hline 306 & 5 & 1 & 1 & 0 & 0 & 0 & 0 & 0 & .03 & .00 & 3 \\
\hline 288 & 13 & 3 & 5 & 1 & 0 & 1 & 0 & 2 & .19 & .00 & 8 \\
\hline 249 & 43 & 11 & 2 & 3 & 0 & 3 & 0 & 2 & .37 & .00 & 8 \\
\hline 253 & 36 & 7 & 7 & 1 & 4 & 1 & 1 & 3 & .42 & .00 & 8 \\
\hline 257 & 36 & 7 & 6 & 3 & 2 & 0 & 0 & 2 & .34 & .00 & 8 \\
\hline 251 & 46 & 7 & 3 & 3 & 2 & 0 & 0 & 1 & .32 & .00 & 8 \\
\hline
\end{tabular}


Trespassed onto

SCHOOL property or

broken into a SCHOOL

$306-6$

1

0

0

0

0

0

0

.03

.00

2

building

Vandalized someone

else's property NOT at

school?

Vandalized SCHOOL

5

3

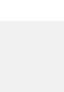

property

297

19

5

3

\section{At SCHOOL, cheated or}

copied someone else's

127

13

work

127

Skipped SCHOOL

without a legitimate

176

24

15

16

excuse

** Items removed prior to conducting the EFA because 5 or few participants endorsed engagement in this behavior. 
Originally, this study made hypotheses that assumed that in-school delinquency and outof-school delinquency were independent of one another, and thus hypotheses were made about each outcome variable separately. In an initial attempt to investigate in-school delinquency and out-of-school delinquency two delinquency scales were first created by separating the 37 items from the delinquency scale by location of which the individual item referred. However, when psychometric analyses were conducted, poor internal consistency was found for both scales. The poor internal consistency of both scales indicated that the items used for the school delinquency scale, and those used for the out-of-school delinquency scale should not necessarily be separated out from one another and included in the noted scales. Students endorsing any specific item on either scale, were not significantly more likely to similarly endorse other items on the scale. Additionally, the two delinquency variables were found to be significantly positively correlated to one another $(r=.87, p<.01)$, with a correlation coefficient that was above .50 , suggesting that the different types of delinquency were likely not independent constructs. Given the high correlation between the two different scales, it was unclear what, if any, underlying factors were present in the delinquency items.

Exploratory factor analysis of delinquency items. At this point, an exploratory factor analysis (EFA) was conducted on the delinquency items in an attempt to parse out what, if any, factors existed within the overarching delinquency construct. Prior to conducting the EFA, the delinquency items that had fewer than five people endorse any level of engagement in a specific behavior were removed from the analyses to reduce the likelihood of finding "factors" with only one item ( $n=6$; see Table 3). The remaining 31 items were entered into an EFA using Maximum Likelihood estimation and a Promax Rotation. 
Table 3

Rotated Pattern Matrix from Exploratory Factor Analysis of Youth-Reported Delinquency Scale, Restricted to Six Factors

\section{$\underline{\text { Factors }}$}

\begin{tabular}{llrrrrr} 
Item & 1 & 2 & \multicolumn{1}{c}{3} & \multicolumn{1}{c}{5} & \multicolumn{1}{c}{5} \\
\hline Knowingly buy, sell, or hold stolen goods NOT at & $\mathbf{. 9 3 2}$ & .043 & -.178 & .079 & -.022 & .165 \\
school & $\mathbf{. 9 2 1}$ & -.101 & .030 & -.090 & .055 & -.192 \\
Sold or dealt drugs or prescription medications AT & $\mathbf{. 8 3 9}$ & .004 & .050 & .249 & -.048 & -.140
\end{tabular}

SCHOOL

Knowingly buy, sell, or hold stolen goods AT

SCHOOL

Sold or dealt drugs or prescription medications

NOT at school

Driven a vehicle while under the influence of

alcohol or drugs

Been involved in a gang fight NOT at school

Trespassed onto someone else's property or broken

into a building NOT at school

Hit someone other than a relative AT SHOOL

While NOT at school, hit someone other than a

relative

Hit one of your parents or another relative

While NOT at school, attacked someone with a

.764

.724

$-.032$

$-.015 \quad .716$

.09

$-.023$

.019

$-.010$

.002

.059

weapon

Been involved in a gang fight AT SCHOOL

Skipped SCHOOL without a legitimate excuse

Carried a hidden weapon NOT at school

At SCHOOL, cheated or copied someone else's

work on an assignment, quiz, or test

Purposely set fire to a house, building, car, or other property NOT at school

Gone into or tried to go into a building to steal

something NOT at school

Stolen or tried to steal money or things worth $\$ 5$ or less, NOT at school

Stolen or tried to steal money or something worth

more than $\$ 5$ but less than $\$ 100$ NOT at school

Trespassed onto SCHOOL property or broken into

SCHOOL

Stolen or tried to steal something worth $\$ 100$ or

more NOT at school 
Table 3 continued

Rotated Pattern Matrix from Exploratory Factor Analysis of Youth-Reported Delinquency Scale, Restricted to Six Factors

\begin{tabular}{|c|c|c|c|c|c|c|}
\hline \multirow[b]{2}{*}{ Item } & \multicolumn{6}{|c|}{ Factors } \\
\hline & 1 & 2 & 3 & 4 & 5 & 6 \\
\hline Vandalized SCHOOL property & -.027 & .051 & .243 & .064 & -.075 & .224 \\
\hline Carried a hidden weapon AT SCHOOL & .090 & .077 & .132 & -.064 & -.020 & .058 \\
\hline $\begin{array}{l}\text { Stolen or tried to steal money or something worth } \\
\text { more than } \$ 5 \text { but less than } \$ 100 \text { AT SCHOOL }\end{array}$ & -.061 & .034 & .025 & 1.07 & -.162 & .162 \\
\hline Gone into SCHOOL building to steal something & .055 & .061 & .289 & .668 & .141 & -.155 \\
\hline Attacked someone with a weapon AT SCHOOL & -.026 & .192 & -.093 & .340 & .046 & -.025 \\
\hline $\begin{array}{l}\text { Stolen money or things worth } \$ 5 \text { or less AT } \\
\text { SCHOOL }\end{array}$ & .009 & .018 & .031 & -.050 & .847 & -.034 \\
\hline Snatched someone's purse/wallet AT SCHOOL & .006 & -.050 & -.137 & .347 & .735 & .190 \\
\hline Vandalized someone's property NOT at school & .065 & .053 & .307 & -.148 & -.069 & .591 \\
\hline Snatched someone's purse/wallet NOT at school & -.019 & -.144 & -.011 & .249 & .122 & .541 \\
\hline Been paid to have sexual relations with someone & .034 & .086 & .043 & .033 & .003 & .127 \\
\hline
\end{tabular}

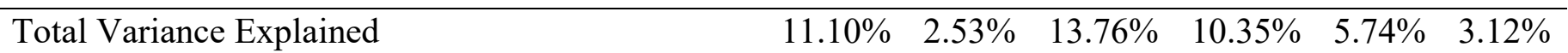

Note. Boldface denotes highest factor loading for each item. 
Initially 10 different factors were found with eigenvalues above 1.0. However, factors nine and ten were found to be primarily comprised of factors that loaded more strongly onto other factors, resulting in Factor 9 including two items, and Factor 10 including only one item. Additionally, it appeared that the items that loaded onto each factor were conceptually indistinguishable. For nearly all cases, both the item that assessed a behavior in school and the item that assessed the same behavior outside of school loaded onto the same factor, suggesting that adolescents engaged in a specific delinquent behavior regardless of context. An EFA was then run forcing the model to extract 8 factors, to see if it could eliminate the smaller crossloading factors found in the initial analysis. That model would not converge after 25 iterations and no meaningful results could be taken from it. However, a third EFA was run forcing the model to extract 6 factors and it successfully converged after 7 iterations explaining 46.57\% of the variance. The pattern matrix showed that eleven items did not have a factor loading at or above .50 on any of the six factors, with ten of those items having a factor loading below .40 (i.e., "At SCHOOL cheated or copied someone else's work on an assignment, quiz, or test for class", and two items with a loading below .20 (i.e., "Been paid for having sexual relations with someone" see Table 3 for factor loadings). Additionally, two items cross-loaded above .30 on two factors. Examining the items on each factor it appears that the first factor loosely represented drug-related behavior, the second factor contained items related to aggressive behavior, and the third factor contained items roughly related to theft. The fifth and sixth factors contained items related to Theft again as well as one item related to sexual misconduct on the sixth factor, but Factor 4 was more heterogeneous in nature. Specifically, Factor 4 contained three items, two dealing with theft and one dealing with aggression. Examination of the items on each factor revealed that similar to the previously examined 10-factor model, a significant portion of the 
homogeneity that was found within a factor was due to the loading of two items that were assessing the same delinquent behavior in different locations. Given this fact, in combination with the fact that the fifth, and sixth factors combine only explained $8.85 \%$ of the variance, the heterogeneous delinquency factors were discarded and the aforementioned total delinquency scale was used for subsequent analyses.

The aforementioned total delinquency count was substituted in place of the originally proposed separate delinquency scales. To address Hypothesis Two, a bivariate correlation was examined between the total delinquency count and the school collective efficacy scale. The two variables were found to be moderately negatively correlated $(r=-.34, p<.01)$. Although this relationship is more general than the originally proposed hypotheses differentiating school delinquency and neighborhood delinquency, the significantly negative correlation between total delinquency and school collective efficacy was consistent with predictions made about the relationship school collective efficacy would have with delinquency.

\section{Hypothesis 3: Associations Between School and Neighborhood Collective Efficacy}

This study also hypothesized that school collective efficacy and neighborhood collective efficacy would be correlated to one another but that the correlated coefficient would be smaller than 0.50 . The two variables were found to be significantly positively correlated $(r=.48, p<$ $.01)$. This result was consistent with predictions made in Hypothesis 3, the two contexts of collective efficacy were related, independent constructs.

\section{Hypothesis 4: Associations Between School Collective Efficacy and Delinquency}

In order to run the path-analysis proposed in Hypothesis 4, school delinquency and neighborhood delinquency would first need to be confirmed independent constructs. Based on their high correlation coefficient as well as each scales' poor internal consistency found when 
examining Hypothesis 2, they were not believed to be two independent constructs, and thus the proposed path analysis was not conducted. Additional regression analyses were used to investigate associations between neighborhood and school collective efficacy, and total delinquency.

Regression examining collective efficacy. In order to further examine the bivariate correlation between neighborhood collective efficacy, school collective efficacy, and delinquency, a hierarchical linear regression was examined. Ethnicity and age were both potential covariate included in the first step of the regression based on preliminary analyses which indicated that each were significantly associated with delinquency. Neighborhood collective efficacy was included in the Step 2 of the model. Based on previous literature (e.g., Sampson, 1997), we would expect neighborhood collective efficacy to be associated with delinquency. School collective efficacy was then added into Step 3 of the model to examine how school-level collective efficacy might influence delinquency beyond neighborhood collective efficacy. Regression results are presented in Table 4. Ethnicity and age were both significantly associated with delinquency. In examining Step 2 of the regression, neighborhood collective efficacy had a significant relationship with total delinquency, and in Step 3, school collective efficacy also had a significant relationship with total delinquency. Once school collective efficacy was added into the model in Step 3, neighborhood collective efficacy no longer had a significant relationship on total delinquency. The finding that school collective efficacy appears to account for the most variance in total delinquency adds support to Hypothesis 4. Specifically, school collective efficacy ultimately overpowered any effect of neighborhood collective efficacy when both independent variables were included into the model, as well as the control variable of ethnicity. This analysis confirms that, in this rural sample, school collective efficacy is more 
strongly associated with self-reported delinquency when compared to neighborhood collective efficacy.

Table 4

Summary of Hierarchical Regression Analysis for Collective Efficacy and Delinquency

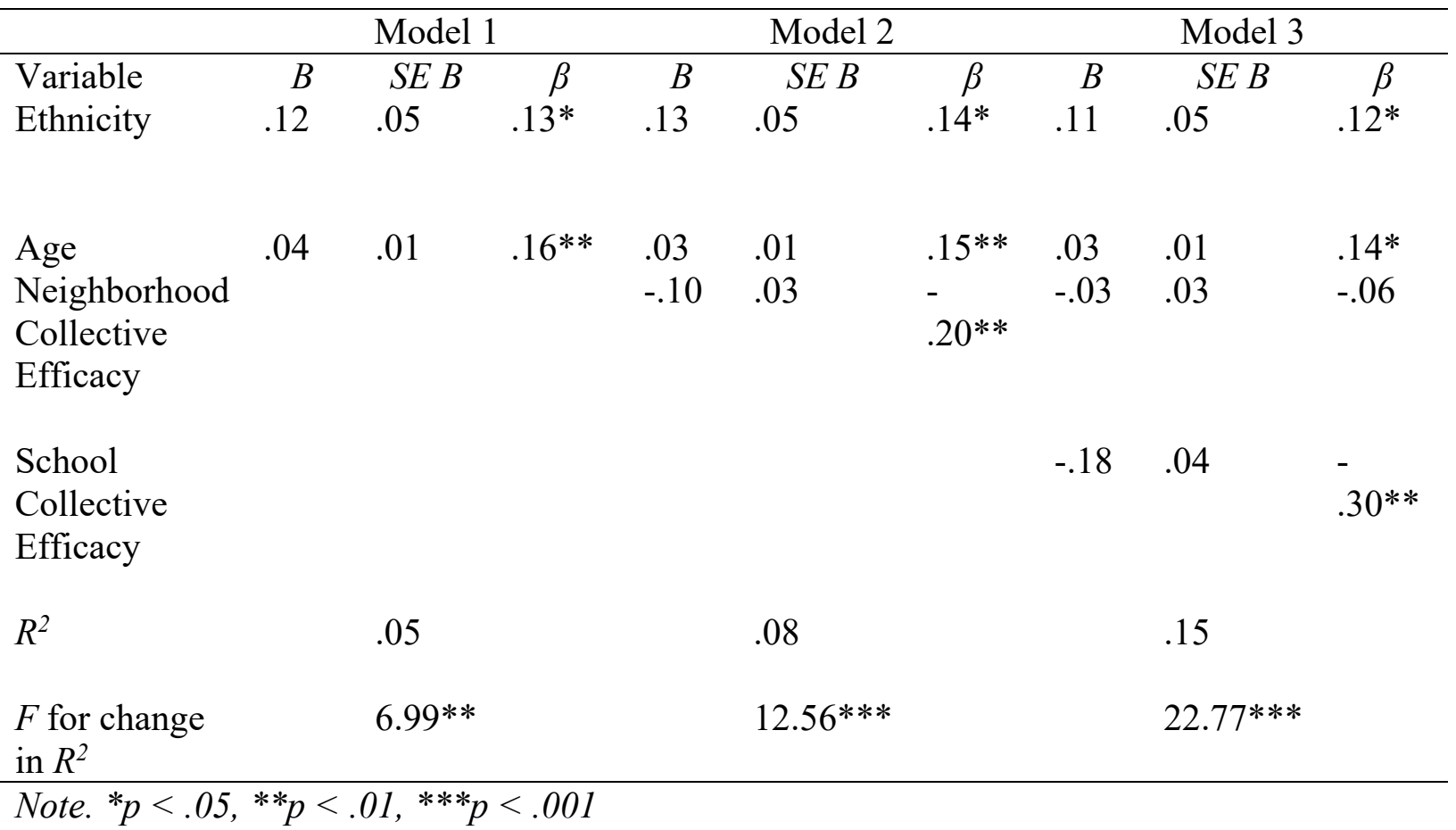

Moderated regression examining connectedness. In order to examine the possibility that school connectedness moderated the effects of school collective efficacy on total delinquency, an exploratory regression analysis was conducted that included an interaction term of school connection by school collective efficacy. A main effect of connectedness on total delinquency was found $\left(\beta=-.19, p<.01 ; R^{2}=.08\right.$, change in $\left.F(1,290)=10.89, p<.01\right)$, as well as a main effect of school collective efficacy on total delinquency $\left(\beta=-.30, p<.01 ; R^{2}=.08\right.$, change in $F(1,289)=28.30, p<.001)$. However, with school collective efficacy included in the model, connectedness no longer had a significant main effect on predicted delinquency $(\beta=-.10$, $p=.10)$. The interaction term of connectedness and school collective efficacy was nonsignificant 
in terms of its association with total delinquency $\left(\beta=.01, p=.79 ; R^{2}=.16\right.$, change in $F(1,288)$ $=.07, p=.79)$. This result suggests that, independent of a student's school connectedness, their perceived level of school collective efficacy may influence their total delinquency score.

\section{Teacher, Staff, Administrator Exploratory Analyses}

As noted above, a small number of teachers, staff, and administrators completed a modified version of the survey, similar to the student survey. A total of 28 teacher/staff/administrator surveys were completed. Given the small number, bivariate correlations were run to examine the relationship between teachers' perceptions of school informal social control and school social cohesion. The mean score for teacher reported school informal social control was $4.19(S D=.51$, while the mean for teacher reported social cohesion was $3.71(S D=.36)$. However, given that school social cohesion and school informal social control are on different scales, it is unclear what these differences may suggest. Unlike students' reports of these constructs, teachers' reports were not significantly correlated $(r=.31, p=.11)$. However, this correlation could only be run on 24 of the 28 completed surveys, due to missing data.

Although formal quantitative comparisons cannot be conducted between teacher and student reports given the small number of teacher respondents, a more qualitative review reveals that teachers tended to perceive their schools to have slightly higher levels of both informal social control and social cohesion when compared to students at their school (see Table 5). 
Table 5

Teachers vs. Students Means for Variables of Interest

\begin{tabular}{lcccc}
\hline & \multicolumn{2}{c}{ District A } & \multicolumn{2}{c}{ District B } \\
Variables & Teachers/Staff/Administrator & Student & Teachers/Staff/Administrator & Student \\
\hline Informal & 4.44 & 3.68 & 3.95 & 3.75 \\
social & & & & \\
control & & & 3.13 & 2.80 \\
\hline Social & 3.71 & 2.57 & & \\
cohesion & & & &
\end{tabular}




\section{CHAPTER IV. DISCUSSION}

The aim of the current study was to fill a gap in the literature on social constructs' influence on juvenile delinquency by exploring an alternative model of rural juvenile delinquency. This new model predicted that in rural areas school-level collective efficacy would be more strongly associated with both in-school and out-of-school problem behaviors when compared to neighborhood-level collective efficacy. This alternative model was based on the underlying assumption that in rural areas, schools act in the same role as "neighborhoods" in Sampson's model of collective efficacy. Schools act as the primary site of peer socialization for children and are the principal settings in which children first encounter peer influences, structure, and collective environmental effects. This is especially true in rural settings where school facilities and grounds are the location of community gatherings such as carnivals, fundraisers, and baby showers. Additionally, rural schools are generally much more clearly defined and conceptualized than geographically determined rural neighborhoods. School districts have clear determinations in terms of who is "part of" your school community and who is not, while in rural areas the construct of "neighborhood" may be difficult to apply. The alternative model, in which rural schools play the role of neighborhoods, was supported and school collective efficacy was found to better predict delinquency when compared to the urban-centric variable, neighborhood collective efficacy. Implications of this finding are discussed below.

This study utilized a sample of 313 junior high and high school students attending two different school districts, both designated by the state of Ohio as being a "rural" district. The districts were also located in Federally designated "Appalachian" counties. The study applied correlations, regressions, and exploratory analyses to assess the relationship between students' perceptions of school characteristics and self-reported juvenile delinquency. Path analyses were 
also proposed, however, given high correlations between the originally proposed outcome variables, these path analyses could not be run and regression analyses were substituted.

\section{Examining School-Level Collective Efficacy}

The construct of school collective efficacy was supported by student reports. The internal consistency for both school informal social control and school social cohesion was acceptable and these constructs were significantly positively correlated to one another, suggesting that they are distinct but related subscales of collective efficacy. This is consistent with Ellonen's (2008) findings supporting the existence of school-level informal social control, as well as Oder's (2005) discussion of school-level social cohesion. This is also consistent with Williams and Guerra's (2011) findings of both school-level informal social control and social cohesion, using measures that were most comparable to Sampson's neighborhood-level measures of informal social control and social cohesion. Additionally, the positively correlated relationship found between these two variables is consistent with what we would expect based on how informal social control and social cohesion relate to one another in the neighborhood context. The current study adds to the new and growing body of literature on students' perceptions of school-level collective efficacy by providing support for the reliability of these constructs within rural schools, a population largely understudied. Researchers are beginning to recognize the importance of considering constructs originally conceived as "neighborhood" constructs within schools, opening new avenues for the study of the school social context.

\section{Neighborhood vs. School Collective Efficacy}

The finding that school collective efficacy and neighborhood collective efficacy are related but separate constructs is important because it suggests that schools have the potential to be different from the neighborhoods they are located in, ultimately affording adolescents another 
"chance" at a positive social influence. For example, if a student lives in area that he/she perceives to have low levels of collective efficacy, that student is at greater risk for engaging in delinquent behavior. However, attending a school that is perceived to have high levels of collective efficacy could potentially protect against the neighborhood effects. The argument that perceived school collective efficacy might be more influential than perceived neighborhood collective efficacy in rural areas is supported by this study's finding that school collective efficacy is more strongly related to delinquency than neighborhood collective efficacy. In practice, this would allow schools a chance to promote cohesion and informal control (the variables that comprise collective efficacy), even if located in neighborhoods that do not contain similar characteristics. This could potentially provide hope to school officials and administrators working in and with schools located in neighborhoods low in perceived collective efficacy, encouraging them to continue efforts to improve school-level collective efficacy. Other researchers have made the point that given the current system of funding related to neighborhood property values, districting lines, and school funding, we would expect that neighborhoods influence schools and students' perceptions of schools and vice versa (Chung, Mulvey, \& Steinberg 2011). Similarly, Cook et al. (2002) posited that these different contexts are related, but emphasized that, at the individual level, context coupling is loose, and that individuals can easily attend an effective school, while living in a neighborhood described as "disorganized." Together, this offers schools the hope that they can strive to create an environment different from the neighborhoods in which they are located. The results of this study, in combination with the steadily growing research on rural neighborhood effects, suggests that this may be particularly true for rural schools. 


\section{Self-Reported Delinquency}

While participants reported distinctions in perceived collective efficacy by neighborhood or school setting, they did not draw such distinctions by the location where delinquent behavior occurred. The original proposed model assumed that in-school delinquency and out-of-school delinquency would be separate constructs. However, delinquent acts that occurred at school were so highly correlated with delinquent acts in the neighborhood that they likely represent one underlying construct. This result suggests that those adolescents that are willing to engage in a delinquent act outside of the school are also likely to engage in other, possible even similar, delinquent acts in the school setting. Previous research has found that, in samples of interest, between $5-10 \%$ of students sampled demonstrate delinquent behaviors in both settings (Herrera \& Little, 2005; Little, Hudson, \& Wilks, 2000). However, these studies generally used parent and teacher report, rather than student self-report, potentially resulting in a perception of rates of similar behaviors between settings. Similarly, when all the delinquency items were included in an EFA, the items that were most likely to load onto factors with one another were the location specific items meant to assess juvenile's engagement in one kind of delinquent behavior across locations. These EFA results support the conclusion that, if an adolescent is willing to engage in a specific delinquent behavior the location of the delinquent behavior, at least when we consider "out-of-school vs. in-school-delinquency," is of little importance.

\section{Regression Analyses of School Collective Efficacy and Delinquency}

Notably, regression analyses supported the two primary hypotheses from this study; perceived school collective efficacy was significantly associated with self-reported delinquency, and this relationship was stronger than the relationship found between perceived neighborhood collective efficacy and student-reported delinquency. Although the initially proposed path 
analyses could not be run, the subsequent regression analyses adequately demonstrated the important role rural school-level collective efficacy plays in predicting juvenile delinquency.

School collective efficacy has a stronger relationship with delinquency than neighborhood delinquency, both in bivariate analyses and in the presence of covariates, supporting the alternative model proposed. This finding suggests that in rural areas, the school could be a more important site for intervention to reduce or prevent delinquency than the community setting. Research on "rural communities" has long been lacking but is slowly growing. However, each study cites similar limitations related to the difficulty in operationalizing "rural neighborhoods," and a number of these studies find results that are both supportive of preexisting urban-centric models and contrasting of these models (Barnett \& Mencken, 2002; Bouffard \& Meftic, 2006; Osgood \& Chambers, 2001). One key finding of both Osgood and Chambers (2001) and Bouffard and Meftic (2006) is that in rural areas, the poorer the area, the less crime is found, directly contrasting the traditional social disorganization theory. These studies concluded that in rural areas, poverty works differently compared to urban areas because it did not necessarily result in residential instability and heterogeneity. If schools indeed do play a larger role at influencing problem behaviors compared to rural communities, it could be that families do indeed move within rural areas, but that these moves are limited to within district lines, resulting in no change to the homogeneity of the school, the institution with the greatest influence on the child. With the finding that schools act seemingly like neighborhoods in rural areas, rural researchers interested in examining the influence of social constructs on rural juvenile delinquency now have another avenue to explore.

School connectedness was found to be significantly negatively correlated to reports of delinquency, and given its similarity to school cohesion, it makes conceptual sense for this 
correlation to be significant. The more connected a student is to his or her school, the lower his or her reported delinquency. Based on this significance, school connectedness was also included in regression analyses to see if it possibly moderated the main effect of perceived school collective efficacy on total delinquency, but this was not supported. The lack of significant moderation for school connectedness suggests that the power of perceived school collective efficacy may be strong enough to influence students' engagement in delinquency behaviors, regardless of how "connected" to the school they feel. Even if students do not feel personally connected to, and supported by, the school they view it as a place that generally monitors and manages the behavior of its students.

\section{Strengths and Limitations}

One key strength of this study is that it adds support to the limited literature positing that urban-centric neighborhood variables like student perceived collective efficacy exist at the school level in rural areas (Ellonen, 2008; Oder, 2005; Plank et al., 2009; Sapouna, 2010; Williams \& Guerra, 2011). The influence of school environments on in-school and out-of-school behavior has been a long-time area of research interest, but only recently have the originally conceptualized neighborhood variables of informal social control and social cohesion been conceptualized as existing in schools. This study's findings that school informal social control and school social cohesion (the two variables that comprise perceived collective efficacy) are independent but correlated supports the idea that these constructs, and thus collective efficacy, indeed exist in a school setting, and that they are uniquely different from one another, further supporting limited existing research.

Another key strength of this study is that it utilized a rural sample. Rural populations are understudied across all aspects of psychology, not only in the juvenile delinquency and 
neighborhood literature. Rural populations are also largely underserved in terms of mental and physical health, community-level policies, and school-level prevention initiatives (U.S. Department of Health and Human Services, Health Resources and Services Administration, 2012). This study supports those that advocate for the importance of recognizing the unique characteristics of rural populations, and hopefully opens up a new path of study that will both inform general theories of community functioning and have practical applications for frontline mental health care providers, school administrators, and educational and judicial policy makers. Many populations are underserved in urban areas as well, however, those populations generally have greater access to resources and transportation infrastructure due to the greater population density. In rural areas, access to resources such as food pantries, shelters, community health clinics, Head Start programs, adult literacy centers, career development services, and others is strained and almost always requires an individual to find transportation or walk long distances with few sidewalks and/or street lights. These unique challenges set rural communities apart from urban and suburban communities, and can limit the generalizability of models developed in urban and suburban settings to rural areas.

The most important aspect of this study is that it was the first of its kind to hypothesize that in rural areas, school-level variables may be more influential on juvenile delinquency when compared to neighborhood-level variables because of the qualitative differences in what a "neighborhood" looks like between rural and urban settings. Although the path analysis which was originally proposed could not be directly assessed, follow-up analyses were run and add preliminary support to the discussed alternative model. Both perceived neighborhood collective efficacy and school collective efficacy were significantly negatively correlated with delinquency as hypothesized. Additionally, the significant correlation of several other variables with 
delinquency suggests that they could act as covariates as hypothesized. The findings of this study contribute to the literature by examining each of these relationships, most notably those involving school collective efficacy, in a rural population and should be explored in future research.

A key limitation of this study is that the number of students who reported delinquency was low, likely due to the combination of a low base rate of many of the delinquency behaviors in this sample, combined with the small sample size. Several delinquency items were only endorsed by five or fewer respondents, across all levels of behavior frequency. Given the predicted base rates of some of these behaviors, it is likely that with a larger sample size, there would be a higher overall frequency of endorsed delinquent items. This limitation was anticipated prior to data collection, and researchers attempted to account for it by adding additional "rural delinquency" measures to Elliott's delinquency questionnaire. However, the "rural delinquency" items were also relatively infrequently endorsed.

Another limitation of this study is that all items, but most notably the delinquency measure was self-report and adolescents completed this measure in a school setting. It is possible that fear of repercussions discouraged them from truthfully endorsing more delinquent acts. In addition, it is important to note that school and neighborhood collective efficacy are individuallevel perceptions, and may not be an accurate reflection of what aggregate measures of collective efficacy, would reveal. A final limitation of this study is that it is cross-sectional in nature, and thus it was not able to assess the potential directionality of the school characteristic-problem behavior relationship. This study presents this relationship as unidirectional, with school characteristics influencing students' willingness to engage in, or modify others' engagement in, 
problem behaviors. However, without data collected from multiple time points, the directionality of this relationship is unknown.

\section{Future Directions}

Future research in this area would benefit from obtaining some objective measure of school environment to use to check against students' self-reported in-school delinquency. In the neighborhood collective efficacy literature, information such as crime statistics are often used to measure neighborhood crime rates. Official school reports of detentions, in-school suspensions, referrals, and other reprimanding actions could offer another layer of insight into the proposed model. A future study of this kind would also benefit from obtaining a larger sample size, ideally from a greater variety of schools. Researchers could then examine, at the school-by-school level, how different levels of aggregated student perceived school collective efficacy are linked to school specific records of delinquent behaviors. Ideally, data should be collected from students at schools with differing levels of "ruralness." This would allow researchers to compare the strength of perceived school collective efficacy and delinquency across different levels of ruralness, and further inform the hypothesis posited by this study. Similarly, future research would benefit from exploring potential objective measures of school-level collective efficacy. When examining Sampson et al.’s (1997) collective efficacy, often objective data about a neighborhood's ethnic heterogeneity, social disadvantage, and residential instability is obtained and compared to residents' perceived collective efficacy. This would allow for future comparisons of students' perceptions with objective data. Eventually, studies may be able to determine which of these two, students' perceptions vs. objective information, is better able to predict student delinquency. 
Another area that future research would likely benefit from pursuing is the inclusion of a larger teacher/staff/administrator sample size. Unfortunately, due to limitations in data collection, only 28 teacher/staff/administrator surveys were completed and no significant statistical results were found, likely due to small sample size. If future studies were to obtain some objective measure of juvenile delinquency in the school setting, then comparisons could be made between teachers' perceptions of school collective efficacy and objective measures of delinquency. This relationship as a whole could be compared to students' perceptions of school collective efficacy and objectives measures of delinquency.

\section{Conclusions and Practical Applications}

This study demonstrates that school-level variables are important especially in rural areas. Although the quantitative data clearly supports this, perhaps the most striking evidence to support the importance of school-level constructs in rural areas was an unexpected piece of qualitative data, indirectly gathered during data collection. Repeatedly during data collection, when completing the "Thoughts about Your Neighborhood" portion of the survey, students would ask researchers "What if I don't live in a neighborhood?" When provided with gentle prompting by the researcher to answer it based on "their opinion of what their neighborhood is," and then to "do their best," students often demonstrated a confused or frustrated facial expression. However, when students were asked almost identical questions while completing the "Thoughts about School" section of the survey, they were easily able to conceptualize "their school" and answer questions about school characteristics without clarification from the researcher. This behavior illustrates one of the significant barriers when trying to conduct research on rural neighborhoods; the unclear and subjective nature of "rural neighborhoods." Further, it is possible that when students were allowed to answer questions about "their 
neighborhood," their school was the community that came to mind. Given that correlations between school collective efficacy and neighborhood collective efficacy were strong, but $<.50$, it is unlikely that all students conceptualized their "neighborhoods" as their school, but it could have contributed to some of the relationship. For nine months out of the year, schools are where adolescents spend the majority of their time, especially in rural areas. Students involved in extracurricular activities often wait at the school for practices and extracurricular activities to begin, even when they may start 2-3 hours after the end of the school day because going home takes time and transportation resources that are not easily available. Throughout summer months, schools are also generally a location for local exercise because rural schools offer some of the most easily available exercise equipment and walking paths. In general, schools are often the hub of community life in rural areas. Future research should include an open-ended question at the end of the survey asking students to briefly describe what they were thinking about when answering questions about their "neighborhood." This information should be qualitatively examined to determine if indeed, students were thinking about their school community when answering neighborhood items. This qualitative information could be used in subsequent research to make data-informed decisions about removing the neighborhood items, or reconceptualizing them in some way to better reflect what students imagine when asked questions about their "neighborhood."

School collective efficacy was shown to be more strongly linked to delinquency, above and beyond the impact of neighborhood collective efficacy. This key point should be carefully considered by school administrators and board members when they are seeking out and developing policy and funding for their schools. It is possible that particular lines of funding, such as athletics, contribute to higher levels of informal social control (ex. The basketball players 
that discourage a fellow teammate from fighting so he can play in the evening game), and/or social cohesion (ex. Students attending sporting events to demonstrate support in others, sharing chants, and a common goal), ultimately impacting overall collective efficacy, and potentially the occurrence of delinquent behaviors in the school and/or neighborhood. This can also be relevant to school administrators and board members when they are considering what types of policies they encourage in terms of student mingling between classes, during study halls and lunches, and after school in student parking lots. For administrators and staff, a common belief is that by allowing students "too much freedom" they are promoting a laissez-faire environment that will eventually lead to problem behaviors. The degree to which limiting "freedom" may discourage building bonds, shared connections, and shared beliefs, should also be considered in the sense that it might limit students' ability to establish and recognize their shared values and goals which make up social cohesion (Hart \& Mueller, 2013). Without the knowledge and understanding that peers in the school ascribe to similar beliefs and values, students may perceive overall lower levels of social cohesion, and thus be less likely to step in to informally manage the behavior of peers in the system (informal social control), ultimately impacting perceived collective efficacy. Faculty, staff, and administrators in rural schools are encouraged to recognize the importance of their school functioning as a community, rather than simply a learning institution, for students and possibly nonstudent community members. School officials should consider how their role as a "community" can be used as an asset to improve student outcomes inside and outside the school, eventually leading to overall growth and development of the school, and the community that it serves. 


\section{REFERENCES}

Anderson, C. S. (1982). The search for school climate: A review of the research. Review of Educational Research, 52(3), 368-420. doi:10.3102/00346543052003368

Barnett, C., \& Mencken, F. C. (2002). Social disorganization theory and the contextual nature of crime in nonmetropolitan counties. Rural Sociology, 67(3), 372-393. doi:10.1111/j.1549$\underline{0831.2002 . t b 00109 . x}$

Battistich, V., \& Hom, A. (1997). The relationship between students' sense of their school as a community and their involvement in problem behaviors. American Journal of Public Health, 87(12), 1997-2001. Retrieved from http://0-

search.ebscohost.com.maurice.bgsu.edu/login.aspx $?$ direct $=$ true $\& d b=a 9 h \& A N=66034 \&$ site $=$ ehos $\underline{\mathrm{t}-\text { live } \& \text { scope }=\text { site }}$

Battistich, V., Solomon, D., Kim, D., Watson, M., \& Schaps, E. (1995). Schools as communities, poverty levels of student populations, and students' attitudes, motives, and performance: A multilevel analysis. American Educational Research Journal, 32(3), 627-658. doi: $10.3102 / 00028312032003627$

Bouffard, L. A., \& Muftić, L. R. (2006). The "Rural Mystique": Social disorganization and violence beyond urban communities. Western Criminology Review, 7(3), 56-66.

Bronfenbrenner, U. (1986). Ecology of the family as a context for human development: Research perspectives. Developmental Psychology, 22, 723-742

Browning, C. R., \& Jackson, A. L. (2013). The social ecology of public space: active streets and violent crime in urban neighborhoods. Criminology, 51(4), 1009-1043.

https://doi.org/10.1111/1745-9125.12026 
Cook, T. D., Herman, M. R., Phillips, M., \& Settersten, Jr., R. A. (2002). Some ways in which neighborhoods, nuclear families, friendship groups, and schools jointly affect changes in early adolescent development. Child Development, 73(4), 1283-1309. doi:10.1111/1467-8624.00472

Chung, H., Mulvey, E., \& Steinberg, L. (2011). Understanding the school outcomes of juvenile offenders: An exploration of neighborhood influences and motivational resources. Journal of Youth and Adolescence, 40(8), 1025-1038.

Crosnoe, R. (2004). Social capital and the interplay of families and schools. Journal of Marriage and Family, 66(2), 267-280. doi:10.1111/j.1741-3737.2004.00019.x

Demanet, J., \& Van Houtte, M. (2012). School belonging and school misconduct: The differing role of teacher and peer attachment. Journal of Youth and Adolescence, 41, 499-514.

Domoff, S. E., Hayman, J., \& Tompsett, C. J. (2012). College students' perceptions of collective efficacy: Results from a nonurban sample. Journal of Community Psychology, 40(6), 762-768. doi: $10.1002 /$ jcop. 21498

Duncan, T. E., Duncan, S. C., Okut, H., Strycker, L. A., \& Hix-Small, H. (2003). A multilevel contextual model of neighborhood collective efficacy. American Journal of Community Psychology, 32(3-4), 245-252. doi:10.1023/B:AJCP.0000004745.90888.af

Elliot, D.S., Wilson, W.J., Huizinga, D., Sampson, R.J., Elliot, A., \& Rankin, B. (1996). The effects of neighborhood disadvantage on adolescent development. Journal of Research in Crime and Delinquency, 33(4), 389-426. doi: 10.1177/0022427896033004002

Ellonen, N. (2008). Adolescent delinquency and social control in Finnish schools: A multilevel analysis. Journal of Scandinavian Studies in Criminology and Crime Prevention, 9(1), 47-64. doi:10.1080/14043850801990357 
Hart, C. O., \& Mueller, C. E. (2013). School delinquency and social bond factors: Exploring gendered differences among a national sample of 10th graders. Psychology in The Schools, 50(2), 116-133.

Haynes, N. M., Emmons, C., \& Ben-Avie, M. (1997). School climate as a factor in student adjustment and achievement. Journal of Educational \& Psychological Consultation,8(3), 321. Retrieved fromhttp://0search.ebscohost.com.maurice.bgsu.edu/login.aspx?direct $=$ true $\& d b=a 9 h \& A N=7437689 \&$ site $=e$ $\underline{\text { host-live } \& \text { scope }=\text { site }}$

Herrera, M., \& Little, E. (2005). Behaviour problems across home and kindergarten in an Australian sample. Australian Journal of Educational \& Developmental Psychology, 5, 577-90.

Kirk, D. S. (2009). Unraveling the contextual effects on student suspension and juvenile arrest: The independent and interdependent influences of school, neighborhood, and family social controls. Criminology: An Interdisciplinary Journal, 47(2), 479-520. doi:10.1111/j.17459125.2009.00147.x

Leventhal, T., \& Brooks-Gunn, J. (2000). The neighborhoods they live in: The effects of neighborhood residence on child and adolescent outcomes. Psychological Bulletin, 126(2), 309337.

Little, E., Hudson, A., \& Wilks, R. (2000). Conduct problems across home and school. Behaviour Change, 17(2), 69-77. doi:10.1375/bech.17.2.69

Marco, A.D., \& Marco, A.M.D. (2010). Conceptualization and measurement of the neighborhood in rural settings: A systematic review of the literature. Journal of Community Psychology, 38, 99114.

Mazerolle, L., Wickes, R., \& McBroom, J. (2010). Community variations in violence: the role of social ties and collective efficacy in comparative context. Journal of Research in Crime and Delinquency, 47(1), 3-30. https://doi.org/10.1177/0022427809348898

McMillan, D. W., \& Chavis, D. M. (1986). Sense of community: A definition and theory. Journal of community psychology, 14(1), 6-23. Retrieved from http://mc7290.bgsu.wikispaces.net/file/view/McMillan_1986.pdf 
Mitchell, M. M., Bradshaw, C. P., \& Leaf, P. J. (2010). Student and teacher perceptions of school climate: A multilevel exploration of patterns of discrepancy. Journal of School Health, 80(6), 271-279. doi:10.1111/j.1746-1561.2010.00501.x

Moffitt, T. E. (1993). 'Life-course-persistent' and 'adolescence limited' antisocial behavior: A developmental taxonomy. Psychological Review, 100, 674-701.

National Crime Victimization Survey. (2014). Washington, DC: U.S. Federal Bureau of Investigation. Retrieved from: http://victimsofcrime.org/docs/default-source/ncvrw2014/urban-rural-crimestatistics-2014.pdf?sfvrsn=2

National Gang Intelligence Center. (2009). National gang threat assessment 2009 (Publication No. 2009-M0335-001). Washington, DC: U.S. Department of Justice.

Odgers, C. L., Moffitt, T. E., Tach, L. M., Sampson, R. J., Taylor, A., Matthews, C. L., \& Caspi, A. (2009). The protective effects of neighborhood collective efficacy on British children growing up in deprivation: A developmental analysis. Developmental Psychology, 45(4), 942-957.

Oder, E. (2005). The social cohesion role of educational organizations: Primary and secondary schools. Peabody Journal of Education, 80(4), 78-88. doi:10.1207/S15327930pje8004_6

Ohio Department of Education. (2015). Typology of Ohio school districts. Retrieved from http://education.ohio.gov/Topics/Data/Frequently-Requested-Data/Typology-of-Ohio-SchoolDistricts

Osgood, D.W., \& Chambers J.M. (2000). Social disorganization outside the metropolis: An analysis of rural youth violence. Criminology, 38, 81-115.

Plank, S. B., Bradshaw, C. P., \& Young, H. (2009). An application of "Broken-Windows" and related theories to the study of disorder, fear, and collective efficacy in schools. American Journal of Education, 115(2), 227-247. doi:10.1086/595669

Roosa, M.W., White, R.M.B., Zeiders, K.H., \& Tein, J.Y. (2009). An examination of the role of perceptions in neighborhood research. Journal of Community Psychology, 37, 327-341. 
Sampson, R. J., Raudenbush, S. W., \& Earls, F. (1997). Neighborhoods and violent crime: A multilevel study of collective efficacy. Science, 277(5328), 918-924. doi: $10.1126 /$ science. 277.5328 .918

Sapouna, M. (2010). Collective efficacy in the school context: Does it help explain victimization and bullying among Greek primary and secondary school students? Journal of Interpersonal Violence,25(10), 1912-1927. doi:10.1177/0886260509354509

Shaw, C. R., \& McKay, H. D. (1942). Juvenile delinquency and urban areas (Vol. xxxii). Chicago, IL, US: University of Chicago Press.

Stewart, E. A. (2003). School social bonds, school climate, and school misbehavior: A multilevel analysis. Justice Quarterly, 20(3), 575-604. doi:10.1080/07418820300095621

U.S. Department of Health and Human Services, Health Resources and Services Administration (2012). Medically underserved areas/populations guidelines for MUA and MUP designation. Retrieved from http://www.hrsa.gov/shortage/mua/index.html United States Census Bureau (2012). 2010 Census Area FAQ. Washington, DC: Author. Retrieved from https://ask.census.gov/faq.php?id=5000\& faqId=5971

Wells, L. E., \& Weisheit, R. A. (2004). Patterns of rural and urban crime: A county-level comparison. Criminal Justice Review,29(1), 1-22. doi:10.1177/073401680402900103

Williams, K. R., \& Guerra, N. G. (2011). Perceptions of collective efficacy and bullying perpetration in schools. Social Problems,58(1), 126-143. doi:10.1525/sp.2011.58.1.126

Witherspoon, D., \& Ennett, S. (2011). An examination of social disorganization and pluralistic neighborhood theories with rural mothers and their adolescents. Journal of Youth and Adolescence, 40(9), 1243-1253. doi:10.1007/s10964-009-9499-4 


\title{
APPENDIX A. PARENT CONSENT LETTER
}

\author{
Bowling Green State University \\ Department of Psychology
}

Dear Parent:

November, 2015

My name is Jennifer Hayman Lackey. I am a doctorate student in clinical psychology at Bowling Green State University in Bowling Green, Ohio. I am writing to ask for your help in understanding how rural schools might help prevent juvenile delinquency. I am currently conducting a survey of middle and high school students, teachers, and administration. This survey will include schools across rural southeast Ohio.

Surveys will be administered by me in your child's classroom. Students will be asked questions about their views on their school and neighborhood. Students will also be asked questions about their self-reported problem behavior including questions about some delinquent behaviors, possible drug and alcohol use, and engagement in sexual behavior. A few examples of questions are at the end of this letter. However, I want to note that students' responses to the survey are completely anonymous.

A blank copy of the survey will be at your child's school. It is available for you to look at for about three weeks from the day your child received this letter. The survey will last about one class period (about 45 minutes). Students do not have to complete the survey if you do not want them to. Students also do not have to complete the survey if they do not want to. Students will be free to stop participating at any time. If you do not want your child to participate, it does not impact their grades or relationship to their school. It also does not impact their relationship with Bowling Green State University. If your child does not participate, they will be given an activity to do, like reviewing a reading assignment, while waiting for their peers to complete the survey.

Risks of participation is minimal. However, in an effort to address even minimal risk students will be provided with a "referral sheet." On this referral sheet will be a crisis hotline number and information about local mental health resources. Students will be told that they can contact the hotline or local mental health center if feeling at all distressed after finishing the survey.

As noted, students' responses to the survey are completely anonymous. Students will be told not to write their names anywhere on the survey. They will not be asked any personal information that could identify them or their families. To ensure anonymity, students will be provided with a blank sheet of paper to cover completed questions. After finishing, students will hand their survey directly to a researcher. The surveys will be placed directly into a manila envelope and stored in a locked file cabinet in my office located off site. Again, students' responses are completely anonymous because we are interested in the responses of students as a group. A similar survey will also be provided to school teachers, staff, and administration.

There are no personal benefits to your child's participation in this study. However, participation gives students an opportunity to voice firsthand their thoughts and opinions about their school environment. Additionally, results may potentially lead to future prevention programs and/or 
interventions. Also, when we analyze the results we will prepare a report that will be shared with the school. The results may help us to better understand rural schools and their influence on students' behaviors.

If you do not want your child to complete the survey, please let us know by returning the attached form WITHIN THREE WEEKS of getting this letter. You can return this form by mailing it back to your child's school. You can also return the survey by sending it back to the school with your child. You can also contact your child's school and tell them that you do not want your child to participate. Not returning the below form indicates your consent for your child to participate.

If you have any questions about the survey please contact me, Jennifer Hayman Lackey, at email: haymanj@bgsu.edu or by phone: 740-416-4943. You may also contact my advisor, Carolyn Tompsett, at cjtomps@bgsu.edu or at (419) 372-8256. If you have any questions or concerns about your child's rights as a research participant please contact the Chair of BGSU's Human Subjects Review Board at (419) 372-7716 (hsrb@bgsu.edu).

I thank you for your consideration.

Sincerely,

Jennifer Hayman Lackey, M.A.

Graduate Student

Department of Psychology

Bowling Green State University 


\title{
APPENDIX B. STUDENT ASSENT LETTER
}

\author{
Bowling Green State University \\ Department of Psychology
}

Dear Student:

October, 2015

My name is Jennifer Hayman Lackey and I am a doctorate student in clinical psychology at Bowling Green State University in Bowling Green, Ohio. I am writing to ask for your help in understanding the importance of rural schools in potentially preventing delinquency in schools and communities. I am currently conducting a survey of middle and high school students, teachers, and administration in schools across rural southeast Ohio

We are asking a random sample of teens in grades 7-12 throughout southeast Ohio to complete an anonymous survey. Anonymous means that you will not write your name on the survey. You will also not write any other information about you, like your birthday or social security number, which could be used to identify you. You will be asked questions about your views about your school and neighborhood. You will also be asked questions about your self-reported problem behavior including questions about possible drug and alcohol use, and sexual behavior.

Examples of questions are at the end of this letter. However, remember that your answers are completely anonymous.

Participation is completely voluntary and you do not have to complete the survey if you do not want to. But, we hope you help because your opinions are important to us! The survey will take about the entire class period to complete. If you decide not to take part, there are no negative consequences. It won't affect your relationship with your teachers or your school. Just let me know after I finish reading this letter if you do not want to participate. You will be given an activity to do while waiting for other students to finish.

Risks of participation are minimal. However, in an effort to address even minimal risk, you can find a resources sheet on the last page of your survey. On this resources sheet is a crisis hotline number and information about local mental health resources. I want to emphasize that if there are questions that you do not feel comfortable answering, just leave them blank. You can stop answering questions at any time. Completing and turning in this survey indicates you're willing to participate.

Your responses to the survey are completely anonymous. You will not write your names anywhere on the survey and will not be asked any personal information that could identify you or your family. No one from the school will be allowed to see your answers, and no one will know exactly what you write. While you are completing the survey you may use the attached piece of paper to cover up questions. When you are finished with the survey, you will hand the survey directly to me. I will place it straight into a manila envelope. We are looking at all the student responses as a group. Some teachers and staff will complete a similar survey to help us better understand differences in beliefs about the school community. 
There are no immediate benefits to your participation in this study. However, this is an opportunity to voice firsthand your thoughts and opinions about your school. Also, the results may help us to better understand rural schools and their role in influencing students' behaviors.

If you have any questions about the survey prior to competition, I will be in this classroom while you complete the survey and available to answer questions. If you have any questions regarding the results after you complete the survey, please contact me, Jennifer Hayman Lackey, at email: haymanj@bgsu.edu or by phone: 740-416-4943. You may also contact my advisor, Carolyn Tompsett, at cjtomps@bgsu.edu or at (419) 372-8256. If you have any questions or concerns about your rights as a research participant please contact the Chair of BGSU's Human Subjects Review Board at (419) 372-7716 (hsrb@bgsu.edu).

I thank you for your consideration.

Sincerely,

Jennifer Hayman Lackey, M.A.

Graduate Student

Department of Psychology

Bowling Green State University

\section{Examples of Questions}

1. Students in my school can be trusted

2. TEACHERS in your school would step in if they saw a student destroying school property

3. Had or tried to have sexual relations with someone against his or her will?

4. Used marijuana? 


\title{
APPENDIX C. TEACHER/STAFF/ADMINISTRATOR RECRUITMENT LETTER
}

Dear Teacher/Staff/Administrator:

November, 2015

My name is Jennifer Hayman Lackey and I am a doctorate student in clinical psychology at Bowling Green State University in Bowling Green, Ohio. I am writing to ask for your help and cooperation in understanding the importance and potential protective factors of rural high schools in predicting and preventing juvenile delinquency in schools and in communities. I am currently conducting a survey of high school students, teachers, and administration in schools across rural southeast Ohio.

We are asking a random sample of school teachers, staff and administrators throughout southeast Ohio to complete an anonymous survey about their perceptions of their school's environment.

This survey will take approximately 15-25 minutes. You do not have to complete this survey if you do not want to, but we hope you help because your opinions are important to us. If you decide not to take part, there are no negative consequences. If you do not want to participate, it does not impact your relationship to your school. It also does not impact your relationship with Bowling Green State University. Completing and turning in this survey indicates your willingness to participate.

Although there are no personal benefits from this study, results from this study may help us to develop better informed prevention programs and interventions that help young people, specifically those in rural areas. There are no anticipated risks of your participation. If there are questions that you do not feel comfortable answering, simply leave them blank. Your responses to the survey are completely anonymous. You will not write your names anywhere on the survey and will not be asked any personal information that could identify you.

I will be at your school during the entire day collecting data with students. Feel free to complete this survey at your leisure. After completion of the survey, you will give the survey directly to the researcher. The survey packet will then be placed directly into a manila envelope and stored in a locked file cabinet in my office at Bowling Green State University. We are interested in your responses as a group. Some students in your school will also complete a similar survey to help us gain a better understanding of differences in beliefs about the school community.

If you have any questions about the survey prior to completion, I will be at your school during the day of data collection and available to answer questions. If you have questions regarding the results after you complete the survey, please contact me, at email: haymanj@bgsu.edu. You may also contact my advisor, Carolyn Tompsett, at cjtomps@bgsu.edu or at (419)372-8256. If you have any questions or concerns about your rights as a research participant please contact the Chair of BGSU's Human Subjects Review Board at (419) 372-7716(hsrb@bgsu.edu).

I thank you for your consideration.

\author{
Sincerely, \\ Jennifer Hayman Lackey, M.A. \\ Graduate Student \\ Department of Psychology \\ Bowling Green State University
}




\section{APPENDIX D. TEACHER/STAFF/ADMINISTRATOR SURVEY}

\section{Teacher/Staff/Administrator Survey}

This is a survey put together by Jennifer Hayman Lackey. This questionnaire asks questions about you-about your opinions, experiences, and feelings. Your responses are anonymous. At no time can your individual responses be singled out and connected to you because we are not collecting names. It is important that you understand this so that you feel free to answer the items as accurately as you can.

\section{Section 1: Thoughts about School}

These questions ask your opinions about your school. Please answer how much each item describes what your school is like. Circle one response for each question.

\begin{tabular}{|l|c|c|c|c|}
\hline & 1 = really disagree & 2 = disagree & 3 = agree & 4 = really agree \\
\hline $\begin{array}{l}\text { Students in my } \\
\text { school can be } \\
\text { trusted }\end{array}$ & 1 & 2 & 3 & 4 \\
\hline $\begin{array}{l}\text { Students in my } \\
\text { school generally } \\
\text { get along with } \\
\text { each other }\end{array}$ & 1 & 2 & 3 & 4 \\
\hline $\begin{array}{l}\text { Students in my } \\
\text { school generally } \\
\text { feel the same } \\
\text { way about things }\end{array}$ & 1 & 2 & 3 & 4 \\
\hline $\begin{array}{l}\text { Teachers in my } \\
\text { school can be } \\
\text { trusted }\end{array}$ & 1 & 2 & 3 & 4 \\
\hline $\begin{array}{l}\text { Teachers in my } \\
\text { school usually get } \\
\text { along with } \\
\text { students }\end{array}$ & 1 & 2 & 3 & 4 \\
\hline $\begin{array}{l}\text { Teachers in my } \\
\text { school generally } \\
\text { feel the same } \\
\text { way about things }\end{array}$ & 1 & 2 & 3 & 4 \\
\hline $\begin{array}{l}\text { This is a pretty } \\
\text { close-knit school } \\
\text { where everyone } \\
\text { looks out for each } \\
\text { other }\end{array}$ & 1 & 2 & & 3 \\
\hline
\end{tabular}




\begin{tabular}{|c|c|c|c|c|c|}
\hline & 1 = very likely & 2 = likely & $\begin{array}{c}3 \text { = neither } \\
\text { likely nor } \\
\text { unlikely }\end{array}$ & $4=$ unlikely & $\begin{array}{l}5=\text { very } \\
\text { unlikely }\end{array}$ \\
\hline $\begin{array}{l}\text { STUDENTS in } \\
\text { your school } \\
\text { would } \\
\text { intervene if } \\
\text { they saw a } \\
\text { student } \\
\text { skipping class } \\
\text { or leaving } \\
\text { school early } \\
\text { without an } \\
\text { excuse }\end{array}$ & 1 & 2 & 3 & 4 & 5 \\
\hline $\begin{array}{l}\text { TEACHERS in } \\
\text { your school } \\
\text { would } \\
\text { intervene if } \\
\text { they saw a } \\
\text { student } \\
\text { skipping class } \\
\text { or leaving } \\
\text { school early } \\
\text { without an } \\
\text { excuse }\end{array}$ & 1 & 2 & 3 & 4 & 5 \\
\hline $\begin{array}{l}\text { STUDENTS in } \\
\text { your school } \\
\text { would step in } \\
\text { if they saw a } \\
\text { student } \\
\text { destroying } \\
\text { school } \\
\text { property }\end{array}$ & 1 & 2 & 3 & 4 & 5 \\
\hline $\begin{array}{l}\text { TEACHERS in } \\
\text { your school } \\
\text { would step in } \\
\text { if they saw a } \\
\text { student } \\
\text { destroying } \\
\text { school } \\
\text { property }\end{array}$ & 1 & 2 & 3 & 4 & 5 \\
\hline
\end{tabular}




\begin{tabular}{|c|c|c|c|c|c|}
\hline & 1 = very likely & 2 = likely & $\begin{array}{c}3 \text { = neither } \\
\text { likely nor } \\
\text { unlikely }\end{array}$ & $4=$ unlikely & $\begin{array}{l}5=\text { very } \\
\text { unlikely }\end{array}$ \\
\hline $\begin{array}{l}\text { STUDENTS in } \\
\text { your school } \\
\text { would help } \\
\text { out to stop } \\
\text { bullying of } \\
\text { another } \\
\text { student }\end{array}$ & 1 & 2 & 3 & 4 & 5 \\
\hline $\begin{array}{l}\text { TEACHERS in } \\
\text { your school } \\
\text { would help } \\
\text { out to stop } \\
\text { bullying of } \\
\text { another } \\
\text { student }\end{array}$ & 1 & 2 & 3 & 4 & 5 \\
\hline $\begin{array}{l}\text { STUDENTS in } \\
\text { your school } \\
\text { would step in } \\
\text { to break up a } \\
\text { fight if one } \\
\text { broke out }\end{array}$ & 1 & 2 & 3 & 4 & 5 \\
\hline $\begin{array}{l}\text { TEACHERS in } \\
\text { your school } \\
\text { would step in } \\
\text { to break up a } \\
\text { fight if one } \\
\text { broke out }\end{array}$ & 1 & 2 & 3 & 4 & 5 \\
\hline
\end{tabular}




\section{Section 2: About You}

The following questions are to help us better understand the overall group of teachers, staff, and administrators, and will not be used to identify you or your answers.

\begin{tabular}{|c|c|c|c|c|c|c|}
\hline $\begin{array}{l}\text { What grade(s) } \\
\text { do you teach? }\end{array}$ & Seventh & Eighth & Ninth & Tenth & Eleventh & \multirow{2}{*}{$\begin{array}{c}\text { Twelfth } \\
19+\end{array}$} \\
\hline $\begin{array}{l}\text { How long have } \\
\text { you been } \\
\text { teaching? }\end{array}$ & 13 & 14 & 15 & 17 & 18 & \\
\hline $\begin{array}{l}\text { What's your } \\
\text { gender? }\end{array}$ & Male & Female & $\begin{array}{c}\text { Prefer not to } \\
\text { answer }\end{array}$ & \multicolumn{3}{|c|}{ Other, please specify } \\
\hline $\begin{array}{l}\text { What's your } \\
\text { race/ethnicity? }\end{array}$ & White & $\begin{array}{c}\text { Hispanic or } \\
\text { Latino/a }\end{array}$ & $\begin{array}{l}\text { Black or } \\
\text { African } \\
\text { American }\end{array}$ & $\begin{array}{c}\text { Native } \\
\text { American } \\
\text { or } \\
\text { American } \\
\text { Indian }\end{array}$ & $\begin{array}{l}\text { Asian or } \\
\text { Pacific } \\
\text { Islander }\end{array}$ & $\begin{array}{l}\text { Other, } \\
\text { please } \\
\text { Specify }\end{array}$ \\
\hline $\begin{array}{l}\text { How long have } \\
\text { you taught at } \\
\text { this school? }\end{array}$ & $\begin{array}{c}\text { Less than } \\
\text { half a } \\
\text { school year }\end{array}$ & $\begin{array}{c}\text { A half - } \\
\text { whole } \\
\text { school year }\end{array}$ & $\begin{array}{c}\text { 1-2 school } \\
\text { years }\end{array}$ & $\begin{array}{c}\text { 2-4 schools } \\
\text { years }\end{array}$ & $\begin{array}{l}\text { 4-6 school } \\
\text { years }\end{array}$ & $\begin{array}{c}6 \text { or more } \\
\text { school } \\
\text { years }\end{array}$ \\
\hline $\begin{array}{l}\text { Which role(s) } \\
\text { best describe } \\
\text { your position } \\
\text { here at the } \\
\text { school? }\end{array}$ & Teacher & Staff & Administrator & Coach & Other, ple & e specify \\
\hline
\end{tabular}




\section{APPENDIX E. STUDENT SURVEY}

\section{Student Survey}

This is a survey put together by Jennifer Hayman Lackey. This questionnaire asks questions about you -about your opinions, experiences, and feelings. Your responses are anonymous. At no time can your individual responses be singled out and connected to you because we are not collecting names. It is important that you understand this so that you feel free to answer the items as accurately as you can.

\section{Section 1: Thoughts about Your Neighborhood}

These questions ask your opinions about your neighborhood. Please answer how much each item describes what your neighborhood is like. Circle one response for each question.

\begin{tabular}{|c|c|c|c|c|c|}
\hline & $\begin{array}{c}1 \text { = Very } \\
\text { Likely }\end{array}$ & 2 = Likely & $\begin{array}{l}\text { = Neither } \\
\text { Likely nor } \\
\text { Unlikely }\end{array}$ & 4 = Unlikely & $\begin{array}{l}5=\text { Very } \\
\text { Unlikely }\end{array}$ \\
\hline $\begin{array}{l}\text { If a group of neighborhood teens } \\
\text { were skipping school and hanging } \\
\text { out on a street corner, how likely is it } \\
\text { that your neighbors would do } \\
\text { something about it? }\end{array}$ & 1 & 2 & 3 & 4 & 5 \\
\hline $\begin{array}{l}\text { If some teens were spray-painting } \\
\text { graffiti on a local building, how likely } \\
\text { is it that your neighbors would do } \\
\text { something about it? }\end{array}$ & 1 & 2 & 3 & 4 & 5 \\
\hline $\begin{array}{l}\text { If a teen was showing disrespect to } \\
\text { an adult, how likely is it that people } \\
\text { in your neighborhood would scold } \\
\text { that teen? }\end{array}$ & 1 & 2 & 3 & 4 & 5 \\
\hline $\begin{array}{l}\text { If there was a fight in front of your } \\
\text { house and someone was being } \\
\text { beaten or threatened, how likely is it } \\
\text { that your neighbors would break it } \\
\text { up? }\end{array}$ & 1 & 2 & 3 & 4 & 5 \\
\hline $\begin{array}{l}\text { Suppose that because of budget cuts } \\
\text { the fire station closest to your home } \\
\text { was going to be closed down by the } \\
\text { city. How likely is it that } \\
\text { neighborhood residents would } \\
\text { organize to try to do something to } \\
\text { keep the fire station open? }\end{array}$ & 1 & 2 & 3 & 4 & 5 \\
\hline
\end{tabular}

Please answer how much you agree with each statement about your neighborhood. 


\begin{tabular}{|l|c|c|c|c|c|}
\hline & $\begin{array}{c}\text { 1 = Strongly } \\
\text { Disagree }\end{array}$ & $\mathbf{2}$ = Disagree & $\begin{array}{c}\text { 3 = Neither } \\
\text { Agree or } \\
\text { Disagree }\end{array}$ & $\mathbf{4}$ = Agree & $\begin{array}{c}\text { 5 = Strongly } \\
\text { Agree }\end{array}$ \\
\hline $\begin{array}{l}\text { People around } \\
\text { here } \\
\text { are willing to } \\
\text { help their } \\
\text { neighbors }\end{array}$ & 1 & 2 & 3 & 4 & 5 \\
\hline $\begin{array}{l}\text { This is } \\
\text { a close-knit } \\
\text { neighborhood }\end{array}$ & 1 & 2 & 3 & 4 & 5 \\
\hline $\begin{array}{l}\text { People in this } \\
\text { neighborhood } \\
\text { can be trusted, }\end{array}$ & 1 & 2 & 3 & 4 & 5 \\
\hline $\begin{array}{l}\text { People in } \\
\text { this } \\
\text { neighborhood } \\
\text { generally } \\
\text { don't get } \\
\text { along } \\
\text { with each } \\
\text { other," }\end{array}$ & 1 & 2 & 3 & 4 & 5 \\
\hline $\begin{array}{l}\text { People in this } \\
\text { neighborhood } \\
\text { do not share } \\
\text { the same } \\
\text { values" }\end{array}$ & 1 & 2 & 3 & & \\
\hline
\end{tabular}


Section 2: Thoughts about School

These questions ask your opinions about your school. Please answer how much each item describes what your school is like. Circle one response for each question.

\begin{tabular}{|c|c|c|c|c|}
\hline & 1 = really disagree & 2 = disagree & 3 = agree & 4 = really agree \\
\hline $\begin{array}{l}\text { Students in my } \\
\text { school can be } \\
\text { trusted }\end{array}$ & 1 & 2 & 3 & 4 \\
\hline $\begin{array}{l}\text { Students in my } \\
\text { school generally } \\
\text { get along with } \\
\text { each other }\end{array}$ & 1 & 2 & 3 & 4 \\
\hline $\begin{array}{l}\text { Students in my } \\
\text { school generally } \\
\text { feel the same } \\
\text { way about things }\end{array}$ & 1 & 2 & 3 & 4 \\
\hline $\begin{array}{l}\text { Teachers in my } \\
\text { school can be } \\
\text { trusted }\end{array}$ & 1 & 2 & 3 & 4 \\
\hline $\begin{array}{l}\text { Teachers in my } \\
\text { school usually get } \\
\text { along with } \\
\text { students }\end{array}$ & 1 & 2 & 3 & 4 \\
\hline $\begin{array}{l}\text { Teachers in my } \\
\text { school generally } \\
\text { feel the same } \\
\text { way about things }\end{array}$ & 1 & 2 & 3 & 4 \\
\hline $\begin{array}{l}\text { This is a pretty } \\
\text { close-knit school } \\
\text { where everyone } \\
\text { looks out for each } \\
\text { other }\end{array}$ & 1 & 2 & 3 & 4 \\
\hline
\end{tabular}




\begin{tabular}{|c|c|c|c|c|c|}
\hline & 1 = very likely & 2 = likely & $\begin{array}{c}3 \text { = neither } \\
\text { likely nor } \\
\text { unlikely }\end{array}$ & $4=$ unlikely & $\begin{array}{l}5=\text { very } \\
\text { unlikely }\end{array}$ \\
\hline $\begin{array}{l}\text { STUDENTS in } \\
\text { your school } \\
\text { would } \\
\text { intervene if } \\
\text { they saw a } \\
\text { student } \\
\text { skipping class } \\
\text { or leaving } \\
\text { school early } \\
\text { without an } \\
\text { excuse }\end{array}$ & 1 & 2 & 3 & 4 & 5 \\
\hline $\begin{array}{l}\text { TEACHERS in } \\
\text { your school } \\
\text { would } \\
\text { intervene if } \\
\text { they saw a } \\
\text { student } \\
\text { skipping class } \\
\text { or leaving } \\
\text { school early } \\
\text { without an } \\
\text { excuse }\end{array}$ & 1 & 2 & 3 & 4 & 5 \\
\hline $\begin{array}{l}\text { STUDENTS in } \\
\text { your school } \\
\text { would step in } \\
\text { if they saw a } \\
\text { student } \\
\text { destroying } \\
\text { school } \\
\text { property }\end{array}$ & 1 & 2 & 3 & 4 & 5 \\
\hline $\begin{array}{l}\text { TEACHERS in } \\
\text { your school } \\
\text { would step in } \\
\text { if they saw a } \\
\text { student } \\
\text { destroying } \\
\text { school } \\
\text { property }\end{array}$ & 1 & 2 & 3 & 4 & 5 \\
\hline
\end{tabular}




\begin{tabular}{|c|c|c|c|c|c|}
\hline & 1 = very likely & 2 = likely & $\begin{array}{c}3=\text { neither } \\
\text { likely nor } \\
\text { unlikely }\end{array}$ & 4 = unlikely & $\begin{array}{l}5=\text { very } \\
\text { unlikely }\end{array}$ \\
\hline $\begin{array}{l}\text { STUDENTS in } \\
\text { your school } \\
\text { would help } \\
\text { out to stop } \\
\text { bullying of } \\
\text { another } \\
\text { student }\end{array}$ & 1 & 2 & 3 & 4 & 5 \\
\hline $\begin{array}{l}\text { TEACHERS in } \\
\text { your school } \\
\text { would help } \\
\text { out to stop } \\
\text { bullying of } \\
\text { another } \\
\text { student }\end{array}$ & 1 & 2 & 3 & 4 & 5 \\
\hline $\begin{array}{l}\text { STUDENTS in } \\
\text { your school } \\
\text { would step in } \\
\text { to break up a } \\
\text { fight if one } \\
\text { broke out }\end{array}$ & 1 & 2 & 3 & 4 & 5 \\
\hline $\begin{array}{l}\text { TEACHERS in } \\
\text { your school } \\
\text { would step in } \\
\text { to break up a } \\
\text { fight if one } \\
\text { broke out }\end{array}$ & 1 & 2 & 3 & 4 & 5 \\
\hline
\end{tabular}


Section 3: Connection to School

The following questions ask about your connection to your friends at school. Please circle the answer that best describes how well each statement applies to you.

\begin{tabular}{|c|c|c|c|c|c|}
\hline & $\begin{array}{c}1=\text { Does not } \\
\text { describe me at } \\
\text { all accurately }\end{array}$ & 2 & 3 & 4 & $\begin{array}{c}5= \\
\text { Describes } \\
\text { me } \\
\text { accurately }\end{array}$ \\
\hline $\begin{array}{l}\text { I wish I had } \\
\text { other friends } \\
\text { at school } \\
\end{array}$ & 1 & 2 & 3 & 4 & 5 \\
\hline $\begin{array}{l}\text { My friends } \\
\text { accept me as } \\
\text { I am }\end{array}$ & 1 & 2 & 3 & 4 & 5 \\
\hline $\begin{array}{l}\text { I trust my } \\
\text { friends at } \\
\text { school } \\
\end{array}$ & 1 & 2 & 3 & 4 & 5 \\
\hline $\begin{array}{l}\text { My friends at } \\
\text { school } \\
\text { respect my } \\
\text { feelings and } \\
\text { ideas }\end{array}$ & 1 & 2 & 3 & 4 & 5 \\
\hline
\end{tabular}


Section 4: Behaviors You've Participated In

The following questions ask about behaviors that you may have engaged in within the past year. For many of the questions, I will ask you separately if you have done the behavior someplace other than school, or in school. Please keep in mind that your answers are anonymous and no one at school will see them. For each question, please think about the past year.

During the past year, how many times have you...

\begin{tabular}{|c|c|c|c|c|c|c|c|c|c|}
\hline & Never & $\begin{array}{l}1-2 \\
\text { times } \\
\text { a year }\end{array}$ & $\begin{array}{l}\text { Once } \\
\text { every } \\
2-3 \\
\text { month } \\
\text { s }\end{array}$ & $\begin{array}{l}\text { Once } \\
\text { a } \\
\text { month }\end{array}$ & $\begin{array}{l}\text { Once } \\
\text { every } \\
2-3 \\
\text { wks }\end{array}$ & $\begin{array}{l}\text { Once } \\
\text { a } \\
\text { week }\end{array}$ & $\begin{array}{l}2-3 \\
\text { times } \\
\text { a } \\
\text { week }\end{array}$ & $\begin{array}{l}\text { Once } \\
\text { a day }\end{array}$ & $\begin{array}{l}2-3 \\
\text { times } \\
\text { a day }\end{array}$ \\
\hline $\begin{array}{l}\text { 1. Purposely set fire to a } \\
\text { house, building, car, or } \\
\text { other property or tried } \\
\text { to do so NOT at school? }\end{array}$ & 0 & 1 & 2 & 3 & 4 & 5 & 6 & 7 & 8 \\
\hline $\begin{array}{l}\text { 2. Purposely set fire to a } \\
\text { building, or other } \\
\text { property AT SCHOOL or } \\
\text { ON SCHOOL GROUNDS? }\end{array}$ & 0 & 1 & 2 & 3 & 4 & 5 & 6 & 7 & 8 \\
\hline $\begin{array}{l}\text { 3. Gone into or tried to go } \\
\text { into a building to steal } \\
\text { something NOT at } \\
\text { school? }\end{array}$ & 0 & 1 & 2 & 3 & 4 & 5 & 6 & 7 & 8 \\
\hline $\begin{array}{l}\text { 4. Gone into or tried to go } \\
\text { into a SCHOOL building } \\
\text { or SCHOOL room to steal } \\
\text { something? }\end{array}$ & 0 & 1 & 2 & 3 & 4 & 5 & 6 & 7 & 8 \\
\hline $\begin{array}{l}\text { 5. Stolen or tried to steal } \\
\text { something worth } \$ 100 \text { or } \\
\text { more NOT at school? }\end{array}$ & 0 & 1 & 2 & 3 & 4 & 5 & 6 & 7 & 8 \\
\hline $\begin{array}{l}\text { 6. Stolen or tried to steal } \\
\text { something worth } \$ 100 \text { or } \\
\text { more AT SCHOOL or a } \\
\text { SCHOOL FUNCTION? }\end{array}$ & 0 & 1 & 2 & 3 & 4 & 5 & 6 & 7 & 8 \\
\hline $\begin{array}{l}\text { 7. Stolen or tried to steal } \\
\text { money or something } \\
\text { worth more than } \$ 5 \text { but } \\
\text { less than } \$ 100 \text { NOT at } \\
\text { school? }\end{array}$ & 0 & 1 & 2 & 3 & 4 & 5 & 6 & 7 & 8 \\
\hline
\end{tabular}




\begin{tabular}{|c|c|c|c|c|c|c|c|c|c|}
\hline $\begin{array}{l}\text { 8. Stolen or tried to steal } \\
\text { money or something } \\
\text { worth more than } \$ 5 \text { but } \\
\text { less than } \$ 100 \mathrm{AT} \\
\text { SCHOOL or a SCHOOL } \\
\text { FUNCTION? }\end{array}$ & 0 & 1 & 2 & 3 & 4 & 5 & 6 & 7 & 8 \\
\hline $\begin{array}{l}\text { 9. Stolen or tried to steal } \\
\text { money or things worth } \\
\$ 5 \text { or less NOT at school? }\end{array}$ & 0 & 1 & 2 & 3 & 4 & 5 & 6 & 7 & 8 \\
\hline $\begin{array}{l}\text { 10. Stolen or tried to } \\
\text { steal money or things } \\
\text { worth } \$ 5 \text { or less AT } \\
\text { SCHOOL or a SCHOOL } \\
\text { FUNCTION? }\end{array}$ & 0 & 1 & 2 & 3 & 4 & 5 & 6 & 7 & 8 \\
\hline $\begin{array}{l}\text { 11. During the past year, } \\
\text { how often did you } \\
\text { knowingly buy, sell, or } \\
\text { hold stolen goods NOT at } \\
\text { school? }\end{array}$ & 0 & 1 & 2 & 3 & 4 & 5 & 6 & 7 & 8 \\
\hline $\begin{array}{l}\text { 12. During the past year, } \\
\text { how often did you } \\
\text { knowingly buy, sell, or } \\
\text { hold stolen goods WHILE } \\
\text { AT SCHOOL? }\end{array}$ & 0 & 1 & 2 & 3 & 4 & 5 & 6 & 7 & 8 \\
\hline $\begin{array}{l}\text { 13. During the past year, } \\
\text { how often have you } \\
\text { snatched someone's } \\
\text { purse or wallet or picked } \\
\text { someone's pocket while } \\
\text { NOT at school? }\end{array}$ & 0 & 1 & 2 & 3 & 4 & 5 & 6 & 7 & 8 \\
\hline $\begin{array}{l}\text { 14. During the past year, } \\
\text { how often have you } \\
\text { snatched someone's } \\
\text { purse or wallet or picked } \\
\text { someone's pocket WHILE } \\
\text { AT SCHOOL or a SCHOOL } \\
\text { FUNCTION? }\end{array}$ & 0 & 1 & 2 & 3 & 4 & 5 & 6 & 7 & 8 \\
\hline $\begin{array}{l}\text { 15. Stolen or tried to } \\
\text { steal a motor vehicle } \\
\text { such as a car or } \\
\text { motorcycle? }\end{array}$ & 0 & 1 & 2 & 3 & 4 & 5 & 6 & 7 & 8 \\
\hline $\begin{array}{l}\text { 16. Carried a hidden } \\
\text { (firearm, pocketknife, } \\
\text { etc.) weapon NOT at } \\
\text { school? }\end{array}$ & 0 & 1 & 2 & 3 & 4 & 5 & 6 & 7 & 8 \\
\hline
\end{tabular}




\begin{tabular}{|c|c|c|c|c|c|c|c|c|c|}
\hline $\begin{array}{l}\text { 17. Carried a hidden } \\
\text { weapon (firearm, } \\
\text { pocketknife, etc.) WHILE } \\
\text { AT SCHOOL or a SCHOOL } \\
\text { FUNCTION? }\end{array}$ & 0 & 1 & 2 & 3 & 4 & 5 & 6 & 7 & 8 \\
\hline $\begin{array}{l}\text { 18. While NOT at school, } \\
\text { attacked someone with a } \\
\text { weapon or with the idea } \\
\text { of seriously hurting or } \\
\text { killing him or her? }\end{array}$ & 0 & 1 & 2 & 3 & 4 & 5 & 6 & 7 & 8 \\
\hline $\begin{array}{l}\text { 19. Attacked someone } \\
\text { with a weapon or with } \\
\text { the idea of seriously } \\
\text { hurting or killing him or } \\
\text { her AT SCHOOL or a } \\
\text { SCHOOL FUNCTION? }\end{array}$ & 0 & 1 & 2 & 3 & 4 & 5 & 6 & 7 & 8 \\
\hline $\begin{array}{l}\text { 20. While NOT at school, } \\
\text { used a weapon, force, or } \\
\text { strong-armed methods to } \\
\text { take money or things } \\
\text { from people? }\end{array}$ & 0 & 1 & 2 & 3 & 4 & 5 & 6 & 7 & 8 \\
\hline $\begin{array}{l}\text { 21. Used a weapon, force, } \\
\text { or strong-armed } \\
\text { methods to take money } \\
\text { or things from people at } \\
\text { SCHOOL or a SCHOOL } \\
\text { FUNCTION? }\end{array}$ & 0 & 1 & 2 & 3 & 4 & 5 & 6 & 7 & 8 \\
\hline $\begin{array}{l}\text { 22. Sold or dealt drugs or } \\
\text { prescription medications } \\
\text { NOT at school? }\end{array}$ & 0 & 1 & 2 & 3 & 4 & 5 & 6 & 7 & 8 \\
\hline $\begin{array}{l}\text { 23. Sold or dealt drugs or } \\
\text { prescription medications } \\
\text { AT SCHOOL or a SCHOOL } \\
\text { FUNCTION? }\end{array}$ & 0 & 1 & 2 & 3 & 4 & 5 & 6 & 7 & 8 \\
\hline $\begin{array}{l}\text { 24. Been paid for having } \\
\text { sexual relations with } \\
\text { someone? }\end{array}$ & 0 & 1 & 2 & 3 & 4 & 5 & 6 & 7 & 8 \\
\hline $\begin{array}{l}\text { 25. Had or tried to have } \\
\text { sexual relations with } \\
\text { someone against his or } \\
\text { her will? }\end{array}$ & 0 & 1 & 2 & 3 & 4 & 5 & 6 & 7 & 8 \\
\hline $\begin{array}{l}\text { 26. Been involved in a } \\
\text { gang fight NOT at school? }\end{array}$ & 0 & 1 & 2 & 3 & 4 & 5 & 6 & 7 & 8 \\
\hline $\begin{array}{l}\text { 27. Been involved in a } \\
\text { gang fight AT SCHOOL or } \\
\text { a SCHOOL FUNCTION? }\end{array}$ & 0 & 1 & 2 & 3 & 4 & 5 & 6 & 7 & 8 \\
\hline
\end{tabular}




\begin{tabular}{|c|c|c|c|c|c|c|c|c|c|}
\hline $\begin{array}{l}\text { 28. Driven a vehicle } \\
\text { while under the } \\
\text { influence of alcohol or } \\
\text { drugs? }\end{array}$ & 0 & 1 & 2 & 3 & 4 & 5 & 6 & 7 & 8 \\
\hline $\begin{array}{l}\text { 29. Hit one of your } \\
\text { parents or another } \\
\text { relative? }\end{array}$ & 0 & 1 & 2 & 3 & 4 & 5 & 6 & 7 & 8 \\
\hline $\begin{array}{l}\text { 30. While NOT at school, } \\
\text { hit someone other than a } \\
\text { relative out of school? }\end{array}$ & 0 & 1 & 2 & 3 & 4 & 5 & 6 & 7 & 8 \\
\hline $\begin{array}{l}\text { 31. Hit someone other } \\
\text { than a relative AT SCHOOL } \\
\text { in a SCHOOL FUNCTION? }\end{array}$ & 0 & 1 & 2 & 3 & 4 & 5 & 6 & 7 & 8 \\
\hline $\begin{array}{l}\text { 32. Trespassed onto } \\
\text { someone else's property } \\
\text { or broken into a building } \\
\text { NOT at school? }\end{array}$ & 0 & 1 & 2 & 3 & 4 & 5 & 6 & 7 & 8 \\
\hline $\begin{array}{l}\text { 33. Trespassed onto } \\
\text { SCHOOL property or } \\
\text { broken into a SCHOOL } \\
\text { building? }\end{array}$ & 0 & 1 & 2 & 3 & 4 & 5 & 6 & 7 & 8 \\
\hline $\begin{array}{l}\text { 34. Vandalized someone } \\
\text { else's property (e.g., } \\
\text { tagged a building, } \\
\text { intentionally damaged } \\
\text { someone's house, } \\
\text { property, mailbox, etc.) } \\
\text { NOT at school? }\end{array}$ & 0 & 1 & 2 & 3 & 4 & 5 & 6 & 7 & 8 \\
\hline $\begin{array}{l}\text { 35. Vandalized SCHOOL } \\
\text { property (e.g., } \\
\text { intentionally damaged } \\
\text { school lockers, desks, } \\
\text { bathroom walls etc.)? }\end{array}$ & 0 & 1 & 2 & 3 & 4 & 5 & 6 & 7 & 8 \\
\hline $\begin{array}{l}\text { 36. At SCHOOL, cheated } \\
\text { or copied someone else's } \\
\text { work on an assignment, } \\
\text { quiz, or test for a class? }\end{array}$ & 0 & 1 & 2 & 3 & 4 & 5 & 6 & 7 & 8 \\
\hline $\begin{array}{l}\text { 37. Skipped SCHOOL } \\
\text { without a legitimate } \\
\text { excuse (e.g., illness, family } \\
\text { emergency, job interview, } \\
\text { transportation problem)? }\end{array}$ & 0 & 1 & 2 & 3 & 4 & 5 & 6 & 7 & 8 \\
\hline $\begin{array}{l}\text { 38. Have you ever been a } \\
\text { member of a gang? (By } \\
\text { gang, we mean a group } \\
\text { that has a name, } \\
\text { identifying }\end{array}$ & \multicolumn{3}{|c|}{ Yes, I'm currently in a gang. } & \multicolumn{3}{|c|}{$\begin{array}{l}\text { Yes, I have in the past } \\
\text { but am not currently in a } \\
\text { gang. }\end{array}$} & \multicolumn{3}{|c|}{$\begin{array}{l}\text { No, I've never been in a } \\
\text { gang. }\end{array}$} \\
\hline
\end{tabular}


colors/clothing, tattoos,

or hand gestures.)

How many times in the past year have you...

\begin{tabular}{|c|c|c|c|c|c|c|c|c|c|}
\hline & $\begin{array}{l}\text { Neve } \\
\mathbf{r}\end{array}$ & $\begin{array}{l}1-2 \\
\text { times } \\
\text { a } \\
\text { year }\end{array}$ & $\begin{array}{l}\text { Once } \\
\text { every } \\
2-3 \\
\text { month } \\
\text { s }\end{array}$ & $\begin{array}{l}\text { Once } \\
\text { a } \\
\text { month }\end{array}$ & $\begin{array}{l}\text { Once } \\
\text { every } \\
2-3 \\
\text { wks }\end{array}$ & $\begin{array}{l}\text { Once } \\
\text { a } \\
\text { week }\end{array}$ & $\begin{array}{l}2-3 \\
\text { times } \\
\text { a } \\
\text { week }\end{array}$ & $\begin{array}{l}\text { Once } \\
\text { a day }\end{array}$ & $\begin{array}{l}2-3 \\
\text { times } \\
\text { a day }\end{array}$ \\
\hline 1. Used marijuana? & 0 & 1 & 2 & 3 & 4 & 5 & 6 & 7 & 8 \\
\hline $\begin{array}{l}\text { Used speed, crack, ice, } \\
\text { or any uppers? }\end{array}$ & 0 & 1 & 2 & 3 & 4 & 5 & 6 & 7 & 8 \\
\hline $\begin{array}{l}\text { 3. Used downers, } \\
\text { tranquilizers, or } \\
\text { sleeping pills? }\end{array}$ & 0 & 1 & 2 & 3 & 4 & 5 & 6 & 7 & 8 \\
\hline $\begin{array}{l}\text { 4. Used downers, } \\
\text { tranquilizers, or } \\
\text { sleeping pills? }\end{array}$ & 0 & 1 & 2 & 3 & 4 & 5 & 6 & 7 & 8 \\
\hline 5. Used crack? & 0 & 1 & 2 & 3 & 4 & 5 & 6 & 7 & 8 \\
\hline 6. Used cocaine? & 0 & 1 & 2 & 3 & 4 & 5 & 6 & 7 & 8 \\
\hline $\begin{array}{l}\text { 7. Used LSD, acid, angel } \\
\text { dust, or other } \\
\text { hallucinogens? }\end{array}$ & 0 & 1 & 2 & 3 & 4 & 5 & 6 & 7 & 8 \\
\hline $\begin{array}{l}\text { 8. Used paint, glue, or } \\
\text { other things you } \\
\text { inhale? }\end{array}$ & 0 & 1 & 2 & 3 & 4 & 5 & 6 & 7 & 8 \\
\hline $\begin{array}{l}\text { 9. Number of times } \\
\text { arrested in the last } \\
\text { year }\end{array}$ & 0 & 1 & 2 & 3 & 4 & 5 & 6 & 7 & 8 \\
\hline
\end{tabular}


Please rate the degree to which you have experienced the following problems in the past $\mathbf{3 0}$ days.

\begin{tabular}{|c|c|c|c|c|c|c|}
\hline & Not at All & $\begin{array}{c}\text { Once or } \\
\text { Twice }\end{array}$ & $\begin{array}{c}\text { Several } \\
\text { Times } \\
\end{array}$ & Often & $\begin{array}{l}\text { Most of the } \\
\text { Time }\end{array}$ & $\begin{array}{c}\text { All of the } \\
\text { Time }\end{array}$ \\
\hline $\begin{array}{l}\text { 1. Arguing } \\
\text { with others }\end{array}$ & 0 & 1 & 2 & 3 & 4 & 5 \\
\hline $\begin{array}{l}\text { 2. Getting } \\
\text { into fights }\end{array}$ & 0 & 1 & 2 & 3 & 4 & 5 \\
\hline $\begin{array}{l}\text { 3. Yelling, } \\
\text { swearing, or } \\
\text { screaming } \\
\text { at others }\end{array}$ & 0 & 1 & 2 & 3 & 4 & 5 \\
\hline $\begin{array}{l}\text { 4. Fits of } \\
\text { anger }\end{array}$ & 0 & 1 & 2 & 3 & 4 & 5 \\
\hline $\begin{array}{l}\text { 5. Refusing } \\
\text { to do things } \\
\text { teachers or } \\
\text { parents ask }\end{array}$ & 0 & 1 & 2 & 3 & 4 & 5 \\
\hline $\begin{array}{l}\text { 6. Causing } \\
\text { trouble for } \\
\text { no reason }\end{array}$ & 0 & 1 & 2 & 3 & 4 & 5 \\
\hline $\begin{array}{l}\text { 7. Using } \\
\text { drugs or } \\
\text { alcohol }\end{array}$ & 0 & 1 & 2 & 3 & 4 & 5 \\
\hline $\begin{array}{l}\text { 8. Breaking } \\
\text { rules or } \\
\text { breaking } \\
\text { the law (out } \\
\text { past curfew, } \\
\text { stealing) }\end{array}$ & 0 & 1 & 2 & 3 & 4 & 5 \\
\hline $\begin{array}{l}\text { 9. Skipping } \\
\text { school or } \\
\text { classes }\end{array}$ & 0 & 1 & 2 & 3 & 4 & 5 \\
\hline 10. Lying & 0 & 1 & 2 & 3 & 4 & 5 \\
\hline
\end{tabular}




\section{Section 5: About You}

The following questions are to help us better understand the overall group of students and will not be used to identify you or your answers.

\begin{tabular}{|c|c|c|c|c|c|c|}
\hline $\begin{array}{l}\text { What grade } \\
\text { are you in? }\end{array}$ & Seventh & Eighth & Ninth & Tenth & Eleventh & Twelfth \\
\hline $\begin{array}{l}\text { How old are } \\
\text { you? }\end{array}$ & 13 & 14 & 16 & 17 & 18 & $19+$ \\
\hline $\begin{array}{l}\text { What's your } \\
\text { gender? }\end{array}$ & Male & Female & $\begin{array}{l}\text { Prefer not } \\
\text { to answer }\end{array}$ & Other, plea & e specify & \\
\hline $\begin{array}{l}\text { What's your } \\
\text { race/ethnicity? }\end{array}$ & White & $\begin{array}{c}\text { Hispanic or } \\
\text { Latino/a }\end{array}$ & $\begin{array}{l}\text { Black or } \\
\text { African } \\
\text { American }\end{array}$ & $\begin{array}{c}\text { Native } \\
\text { American } \\
\text { /American } \\
\text { Indian } \\
\end{array}$ & $\begin{array}{l}\text { Asian or } \\
\text { Pacific } \\
\text { Islander }\end{array}$ & $\begin{array}{l}\text { Other, } \\
\text { please } \\
\text { Specify }\end{array}$ \\
\hline $\begin{array}{l}\text { How long have } \\
\text { you attended } \\
\text { this school? }\end{array}$ & $\begin{array}{c}\text { Less than } \\
\text { half a } \\
\text { school year }\end{array}$ & $\begin{array}{c}\text { A half - } \\
\text { whole } \\
\text { school year }\end{array}$ & $\begin{array}{c}\text { 1-2 school } \\
\text { years }\end{array}$ & $\begin{array}{c}\text { 2-4 schools } \\
\text { years }\end{array}$ & $\begin{array}{l}\text { 4-6 school } \\
\text { years }\end{array}$ & $\begin{array}{c}6 \text { or more } \\
\text { school } \\
\text { years }\end{array}$ \\
\hline $\begin{array}{l}\text { About how } \\
\text { long is your } \\
\text { drive to } \\
\text { school? }\end{array}$ & $\begin{array}{l}\text { Less than } \\
10 \text { minutes }\end{array}$ & $\begin{array}{l}10-20 \\
\text { minutes }\end{array}$ & $\begin{array}{c}20-40 \\
\text { minutes }\end{array}$ & $\begin{array}{l}\text { 40-60 } \\
\text { minutes }\end{array}$ & $\begin{array}{l}\text { More than } \\
60 \text { minutes }\end{array}$ & \\
\hline $\begin{array}{l}\text { How would } \\
\text { you describe } \\
\text { the area you } \\
\text { live? }\end{array}$ & In town & $\begin{array}{c}\text { Out of town } \\
\text { with lots of } \\
\text { close } \\
\text { neighbors }\end{array}$ & $\begin{array}{c}\text { Out of } \\
\text { town with } \\
\text { some close } \\
\text { neighbors }\end{array}$ & $\begin{array}{l}\text { Out of town } \\
\text { with no } \\
\text { close } \\
\text { neighbors }\end{array}$ & & \\
\hline $\begin{array}{l}\text { How long have } \\
\text { you lived at } \\
\text { your current } \\
\text { home? }\end{array}$ & $\begin{array}{l}\text { Less than a } \\
6 \text { months }\end{array}$ & $\begin{array}{c}\text { 6-12 } \\
\text { months }\end{array}$ & $1-2$ years & $2-4$ years & $4-6$ years & $\begin{array}{c}6 \text { or more } \\
\text { years }\end{array}$ \\
\hline $\begin{array}{l}\text { About how long } \\
\text { would it take } \\
\text { you to walk } \\
\text { from your front } \\
\text { door to your } \\
\text { closest } \\
\text { neighbor's } \\
\text { house? }\end{array}$ & $\begin{array}{c}\text { No time, } \\
\text { they live } \\
\text { right beside } \\
\text { me }\end{array}$ & $\begin{array}{c}\text { Less than } 5 \\
\text { minutes }\end{array}$ & $\begin{array}{c}\text { 5-10 } \\
\text { minutes }\end{array}$ & $\begin{array}{c}10-15 \\
\text { minutes }\end{array}$ & $\begin{array}{c}15-20 \\
\text { minutes }\end{array}$ & $\begin{array}{c}\text { More than } \\
20 \\
\text { minutes }\end{array}$ \\
\hline $\begin{array}{l}\text { About how } \\
\text { many occupied } \\
\text { neighboring } \\
\text { houses are } \\
\text { within that } \\
\text { distance of } \\
\text { walk? }\end{array}$ & None & $1-2$ & $3-4$ & $5-6$ & 7 or more & \\
\hline
\end{tabular}




\section{APPENDIX F. HSRB APPROVAL LETTER}

\section{BGSU。}

BOWLING GREEN STATE UNIVERSITY

DATE:

TO:

FROM:

PROJECT TITLE:

SUBMISSION TYPE:

ACTION:

APPROVAL DATE:

EXPIRATION DATE:

REVIEW TYPE:

REVIEW CATEGORY:
June 2, 2016

Jennifer Lackey, M.A.

Bowling Green State University Human Subjects Review Board

[747869-6] A New Model of Rural Delinquency: Collective Efficacy in Rural Schools

Continuing Review/Progress Report

APPROVED

June 3, 2016

June 2, 2017

Full Committee Review

Full Committee

Thank you for your submission of Continuing Review/Progress Report materials for this project. The Bowling Green State University Human Subjects Review Board has APPROVED your submission. This approval is based on an appropriate risk/benefit ratio and a project design wherein the risks have been minimized. All research must be conducted in accordance with this approved submission.

Please note that you are responsible to conduct the study as approved by the HSRB. If you seek to make any changes in your project activities or procedures, those modifications must be approved by this committee prior to initiation. Please use the modification request form for this procedure.

You have been approved to enroll 800 participants. If you wish to enroll additional participants you must seek approval from the HSRB.

All UNANTICIPATED PROBLEMS involving risks to subjects or others and SERIOUS and UNEXPECTED adverse events must be reported promptly to this office. All NON-COMPLIANCE issues or COMPLAINTS regarding this project must also be reported promptly to this office.

This approval expires on June 2, 2017. You will receive a continuing review notice before your project expires. If you wish to continue your work after the expiration date, your documentation for continuing review must be received with sufficient time for review and continued approval before the expiration date.

Good luck with your work. If you have any questions, please contact the Office of Research Compliance at 419-372-7716 or hsrb@bgsu.edu. Please include your project title and reference number in all correspondence regarding this project.

This letter has been electronically signed in accordance with all applicable regulations, and a copy is retained within Bowling Green State University Human Subjects Review Board's records. 